\title{
Chapter 1 \\ Improving Water Management and the Water Management System in the Liao River Basin and Lake Dian
}

\author{
Ke Chen and Markus Disse
}

\subsection{Structural Indicators}

With increased political and academic concerns, the term "water governance" has been debated that it responds to challenges of sustainable development [42]. The Organization for Economic Co-operation and Development (OECD) defines water governance as a "range of political, institutional and administrative rules, practices and processes (formal and informal) through which decisions are taken and implemented, stakeholders can articulate their interests and have their concerns considered, and decision makers are held accountable for water management" [35]. Good water governance thus depends on several significant factors, including strong legal, policy and regulatory framework, effective administrative and institutional framework that facilitates collaboration among various water organizations; civic determinations for sustaining good water environment and adequate investments [10]. Actually, the term of Integrated Water Resources Management (IWRM) can be described by technical and management approaches, wherein the management approaches can be divided into "Good Water Governance Structures, Water Rights, Financing, Communication, Human Factors and Cultural Impacts" [11]. Having a closer look to the Good Water Governance Structure, it comes out that there in absolutely no common design of water institutions but in the opposite any culture has developed very individual ways to organize the water issue. This is remarkable, because the water issue itself globally is not that different: water is needed by any life, is a typically regional or temporally changing resource, from drought seasons to abundant up to floods and water is running downhill, which connects needs of any living thing in the river basin in a competitive way. So, the water governance is a result of an institutional, legal and cultural organization of any existing state or society, which is at least

K. Chen $\cdot$ M. Disse $(\varangle)$

Chair of Hydrology and River Basin Management, TUM Department of Civil, Geo and Environmental Engineering, Technical University of Munich, Munich, Germany

e-mail: markus.disse@tum.de 
complicated if not complex because it involves actually any form of state structure, from the highest level (State) down to the lowest subsidiary level (communities, clans, families) [12]. This factor water institutional framework (water governance structure) plays a strong role in affecting the overall water governance performances. While effective water institutional framework helps to shape the choices made within water resource management, it reflects the stakeholders with their respective goals, features the fractures and balances of powers, determines the controlling and collaborative mechanism among water relevant organizations and ensures collective actions against existing and new challenges $[6,38]$. Thus, arguments have been made that water resource governance depends strongly on placement of institutional arrangements, and water institutional framework is of vital importance in ensuring water security $[14,41]$. Therefore, understanding the relevant organizations and their institutional dynamics could facilitate the stakeholders and decision makers to conduct effective water management measures.

\subsubsection{Development of Innovative 3D Water Governance Models for Kunming City and Bavaria}

\subsubsection{Introduction}

It has been recognized that any institutional framework, including water sector, could reflect its several intrinsic dynamic aspects, such as the formal and informal scheme of relationships, patterns and channels of communication and operating processes for routine and exceptive management tasks [1, 19]. If taking the structure of the organization of the society as the "hardware", it also requires understanding the "software", meaning the written and unwritten rules of cooperating and teamworking to understand the management. Thus, these management processes of various water governance tasks are of great importance, while they are designed to resolve manifold water relevant issues, respond appropriately against emergent and exceptive situations and reflect concretely how water laws and regulations are implemented in practical actions [6,36], Saleth and Dinar 2013). A good way to describe this cooperation is a "process-model", which means describing the workflow shown in a diagram. Therefore, it is crucial to systematically demonstrate different management processes over all involved institutions, which might be a lot for reviewing their competences on practical applications.

Practically, water institutional framework charts are usually drawn to understand water governance structures for different nations or regions, study examples can be seen from [8], Ministry of Water and Environment of Uganda (MWE n.d.), [34] and [44]. Those charts are mostly drawn in various types of 2D layouts and commonly place water relevant organizations at different positions, depending on their hierarchies and organizational functions. On the other hand, water management processes are also commonly depicted in 2D layouts by different forms of flow charts, such 
examples can be seen from the studies of Bavarian Environment Agency (LfU) (LfU n.d.a, 2010) and [31].

Although the 2D layouts of water institutional frameworks and management processes provide adequate view and understanding of water governance structures and procedures, essential drawbacks also exist. Firstly, since organizations always communicate within the environment of other organizations at parallel and hierarchically levels, namely horizontally and vertically, a 3D relationship thus exists (Grambow et al. 2017). However, water institutional frameworks shown in 2D formats intrinsically could not express such a characteristic. Secondly, water institutional frameworks in 2D layouts cannot fully present all relevant organizations, thus the scale of water governance structures within a specific region could not be viewed in accurate dimensions. Thirdly, regarding the display of water management process charts, usually they are demonstrated statically out of the entire water institutional framework, and provide only limited descriptive information, thus essential background and supportive information is not provided for optimized understanding. Hence, the authors consider that conventional 2D approaches for exhibiting water governance structures and management processes cannot fully express and comprehend the complexity of water institutional structures as well as the spatial dynamic essence of management processes.

The authors have conducted extensive literature reviews to find if there is the existence of previous studies that aimed at developing the 3D water institutional framework (model), and resolved these above-mentioned drawbacks, however, no similar studies have been discovered. In this study, the authors aim at developing two integrative 3D Water Governance Models (3D-WGM) that enable to exhibit all relevant water organizations for the study areas Kunming City, China and Bavaria, Germany, and interactively demonstrate various representative water management processes within the models. In addition, numerous functions are also intended to be incorporated in the 3D-WGMs for facilitating the models' operation.

\subsubsection{Materials and Methods}

\section{Study Areas}

With the formation of German research initiative International Partnerships for Sustainable Technologies and Services for Climate Protection and the Environment (CLIENT), which is funded by the German Federal Ministry of Education and Research (BMBF), several projects were launched to support China in solving water resource management challenges in selected areas [9]. Within the CLIENT framework, SINOWATER Project was initiated that aims at advancing Good Water Governance, management and innovative technologies for improving the water quality of Dianchi Lake (falls in Kunming City) and Liao River Basins, where both basins were selected while they are regarded as two of the most important and most heavily polluted water bodies in China. On the other hand, the German experience from Bavarian water resource management and administration was selected in SINOWATER Project to conduct comparative studies for providing water governance 
strategies and executive suggestions. This study, as a contribution to SINOWATER Project, then chooses the water governance system in Kunming City, China and Bavaria, Germany as study areas.

\section{Kunming City}

The first study area where this research was conducted is Kunming City. As a capital city of Yunnan Province, China, Kunming City is located at an altitude of 1,890 m in southwest China, which covers a total area of $21,012 \mathrm{~km}^{2}$ [27]. The climate of Kunming City is classified as subtropical highland climate (Köppen Cwb) and characterised by warm and humid summers, and cool and dry winters. With one of the mildest climate in China, Kunming City has an annual mean temperature of $15.52{ }^{\circ} \mathrm{C}$ and precipitation of $979 \mathrm{~mm}$. The population of Kunming City has reached 6.626 million in which 4.575 million are resided in urbanized regions [45].

A large lake named Dianchi Lake is located at southwest within the jurisdiction of Kunming City. Throughout history, Dianchi Lake has been important for the economy and tourism development as well as many aspects of residents' livelihood in Kunming City. Ranked as the 6th largest freshwater lake in China, Dianchi Lake covers an area of $309.5 \mathrm{~km}^{2}[15,17]$. Over last few decades of rapid economic and population growth, and combined with significant increase of urbanization rate and land use changes, continuous increased pollutant discharges from rural and urban areas have caused severe water quality deterioration and eutrophication of Dianchi Lake, in the meanwhile, ecosystem of Dianchi Lake Basin has been reported that went through a tremendous degradation [15, 27-29].

Since 1980s, the severe water pollution condition in Kunming City, mainly arose from Dianchi Lake Basin, has been widely recognized by national and local governments. Through years of implementing pollution control actions, central and local governments have recognized that fundamental water environment enhancement must be accompanied by strategies of Good Water Governance. Thus, lessons learned regarding water management have been systematically reviewed, and plans in association with water governance were revised and supplemented into existing and future development polices, where the topic of comprehensive understanding and analysis of current water administration systems was also regarded as one of the major future tasks [29].

\section{Bavaria}

The second study area is targeted at Bavaria that locates in southeast of Germany. As the largest state in Germany by land area, Bavaria covers a total area of $75,500 \mathrm{~km}^{2}$. With population amounts to 12,976 million [2], Bavaria is ranked as the second-mostpopulous state in Germany. While lying in transitional area from Western Europe to Eastern Europe, Bavaria receives climate patterns, which ranges from oceanic climate (Köppen Cfb) to continental climate (Köppen Dfb) (LfU n.d.b). Precipitation also varies greatly both regionally and temporally, on average the total annual precipitation in Bavaria amounts to $933 \mathrm{~mm}$, while in northern Bavaria, it reduces to $768 \mathrm{~mm}$ and southern Bavaria reaches 1,058 mm (LfU n.d.c). 
Bavaria is a relative water-rich state in Germany, in total $2 \%$ of its whole land area, namely $1,446 \mathrm{~km}^{2}$ is covered by water resources. Approximately, the lengths of all rivers and streams in Bavaria are added up to $100,000 \mathrm{~km}$, where around $9,000 \mathrm{~km}$ water bodies are regarded with regional and supra-regional significances [40]. Bavaria also forms parts of three international river basins, namely Danube, Rhine and Elbe, and play important roles in their commissions for protecting river basin environment with joint efforts. With respect to surface water quality in Bavaria, at current stage, the chemical status is overall at good condition (nearly $95 \%$ of all the surface water bodies) when not considering the ubiquitous substances, nevertheless, on the other hand, only around $15 \%$ of all surface water bodies have reached the ecological good status [26].

History of water management administration in Bavaria dates to 18th Century, until today, steady governmental structures have been formed, which are responsible for sustainable utilization and management of water resources [40]. As members of various task forces (e.g. ARGE Alp, Arge Alpen-Adria) and international river basin commissions (i.e. Rivers Danube, Rhine and Elbe), Bavaria takes further responsibilities of securing healthy water environment in Europe. Furthermore, Bavarian water management administration also extends international collaborations and communications at global scales. Through multiple international collaborative phases, it has been noticeable that each nation or region administrates water resources with its unique governmental and public institutional arrangements, thus it stimulates Bavarian water management administration to systematically and in-depth understand its own water administrative structure as well as the regions with partnerships, such as China, India, Tunisia and Poland.

\section{Establishment of 3D Water Governance Models Selection of Modelling Software and Programming}

Through a wide range of selections, the authors have chosen Unity, a popular interactive $3 \mathrm{D}$ rendering engine, to build the $3 \mathrm{D}-\mathrm{WGMs}$. We have designed an appropriate description format to encode the water institutional structures in regular Microsoft Excel tables, which are capable of fast and batched data edition, and every time when Unity software launches, it reads all the data into memory and produces the corresponding 3D representation. In this way, meta-data of organizations appeared in the models are separated from programming code to achieve independent editing of organizational data. Hence, each single organization in the 3D-WGMs could be assigned with different sizes in 3D shapes and collectively shown in one single model. Since the 3D-WGMs are required to integrally exhibit abundant of organizations, we have used GPU instancing technique [18], which enabled to render large amount of $3 \mathrm{D}$ units in different colours and sizes on one screen in $60 \mathrm{~Hz}$ (frame per second, FPS).

Regarding the realization of demonstrating water management processes, we have designed a novel data structure to describe their step-by-step action flows. With this structure, the 3D-WGMs enables to exhibit the action flows as 3D animations in real-time, interactively. In these animations, the models sequentially draw lines connecting two specific units as a representation of actual workflow. When animation 
encounters branches, a dialog window appears to allow users to choose different options.

\section{Model Construction}

With the application of Unity Software, graphical User Interfaces (UI) and various associated applicable functions were developed for both models in Kunming City and Bavaria.

In the first place, each single unit, namely every relevant organization demonstrated in the models, was inserted and assigned with specific 3D shape and colour depending on its type and function. The function of displaying internal structure was incorporated, which allows users to zoom into a specific organization to observe its internal construction at different scales. Subsequently, map images with high resolution, which indicate administrative divisions at different hierarchies were vertically placed with sequences in the models, afterwards, each organization (i.e. the equivalent 3D shape) was placed above the corresponding map for expressing itself as an official organization in the specific area. In addition, each organization was programmed that enables to be edited to provide supplementary literal information (text box placed to display at top-left corner of UI, see model conception Fig. 1.1) for explaining its properties and characteristics.

In the next phase, the function of illustrating the dynamic procedure flows of various representative water management processes both for Kunming City and Bavaria was designed. Every water management process was represented by an interactive button, which is located at top-right of the Model UI (Fig. 1.1). By clicking any of those buttons, the model will initiate to dynamically illustrate this specific water management process step by step, and each action step was realized by utilizing a $3 \mathrm{D}$ arrow pointing from one organization to another. In addition, the full literal

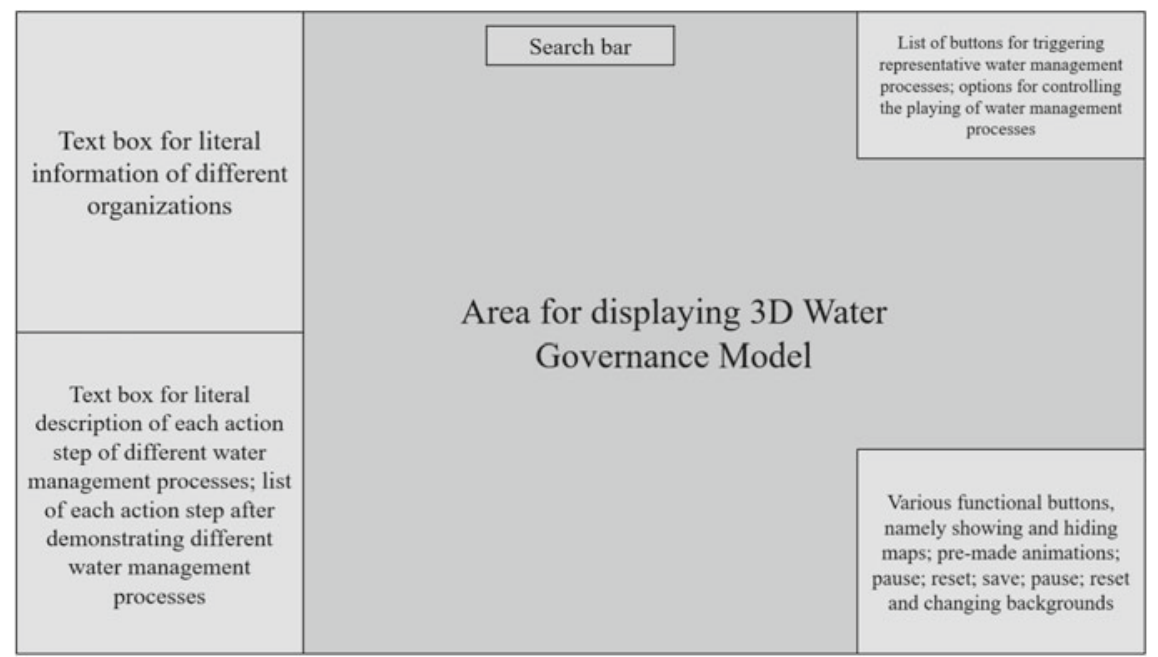

Fig. 1.1 Interface conceptual design of 3D-WGMs 
description of each action step was arranged to accompany throughout the illustrative processes, which is placed at the bottom-left of the Model UI (Fig. 1.1). At the end of dynamic illustration of process flows, each relevant action step was arranged to be placed again in order on the Model UI (bottom-left corner, Fig. 1.1) for further understanding, and every step was programmed to link with its corresponding action arrow, which simultaneously shall be highlighted as well.

At later stage of model development, several significant auxiliary functions such as hiding or displaying any 3D unit and map, changing UI background and searching functions (Fig. 1.1), were embedded for facilitating its practical utilization.

\section{Model Information Input}

In order to understand and obtain background information to support the establishment of 3D-WGMs, extensive literature reviews both for Kunming City and Bavaria regarding the understanding of water management related institutional arrangements and process descriptions were firstly conducted. During this process, various types of literatures and documents, such as journal articles, official internet documents, reports, statutes, and regulations were retrieved, analyzed and arranged.

Based on essential literature reviews, two rounds of systematic and semistructured interviews were subsequently conducted both in Kunming City and Bavaria for gathering supplementary information of model establishment. All interviews were executed by the first author and were audio-taped and partially verbatim transcribed. In the first round, according to necessities, interviews were conducted within various representative water relevant organizations in Kunming City and Bavaria. The first-round interviews aimed at clarifying water management structural and institutional constructions. In the second round of interviews, it was designed to explicitly determine the step-by-step description of each selected representative water management process, every single process detail was verified with local water management officers, who are closely involved within those procedures.

\subsubsection{Results}

\section{Construction of 3D Water Governance Models}

\section{Graphical User Interface}

As results of model development, two individual 3D-WGMs are built for Kunming City and Bavaria respectively. By opening the designated executive file, the User Interface (UI) of Bavarian model presents in the first place. While the model interface integrates both models (Kunming City and Bavaria), it allows users to switch between two models by clicking the appointed button. Since both models are designed with similar UI, thus, in this section, the graphical user interface will be introduced and explained with the example of Bavarian 3D-WGM (Fig. 1.1). The model is composed of several zones, which are numbered and will be elaborated in sequence in the following lines. 
1. The first zone represents text boxes, which allows users to enter and edit literal contents for any organization shown in the model. Within the text boxes, users could attach various kinds of documents, such as PDFs, pictures, and video files, for its extended explanation. The text box appears instantly when the mouse cursor is pointed to a specific organization and could be closed manually or replace contents, when the cursor is pointed to another organization.

2. The second zone is reserved for displaying another type of text box, which consists of the description of each action step from any water management process. It is only activated when the process is triggered (see number (5)).

3. The third zone exhibits the main body of the 3D-WGMs. The example in Fig. 1.2 is shown from a specific spatial angle and composed of three parts. In the left part, all the water relevant official organizations are arranged according to their hierarchies and geographical locations on maps. In the right part of this zone, various social organizations, which are involved in water management system, are adjacently displayed above an independent surface. In the middle part, some organizations are placed temporarily, when further arrangement for their positions are necessary.

4. In the fourth zone, namely at the top-middle area of the UI, a search bar is inserted that allows user to search any specific organization, which exists in the model.

5. A list of buttons, which indicates the selected water management processes, is placed in the fifth zone. By clicking any of the buttons, it triggers the dynamic procedure flow of that specific process. During the procedure flow, each

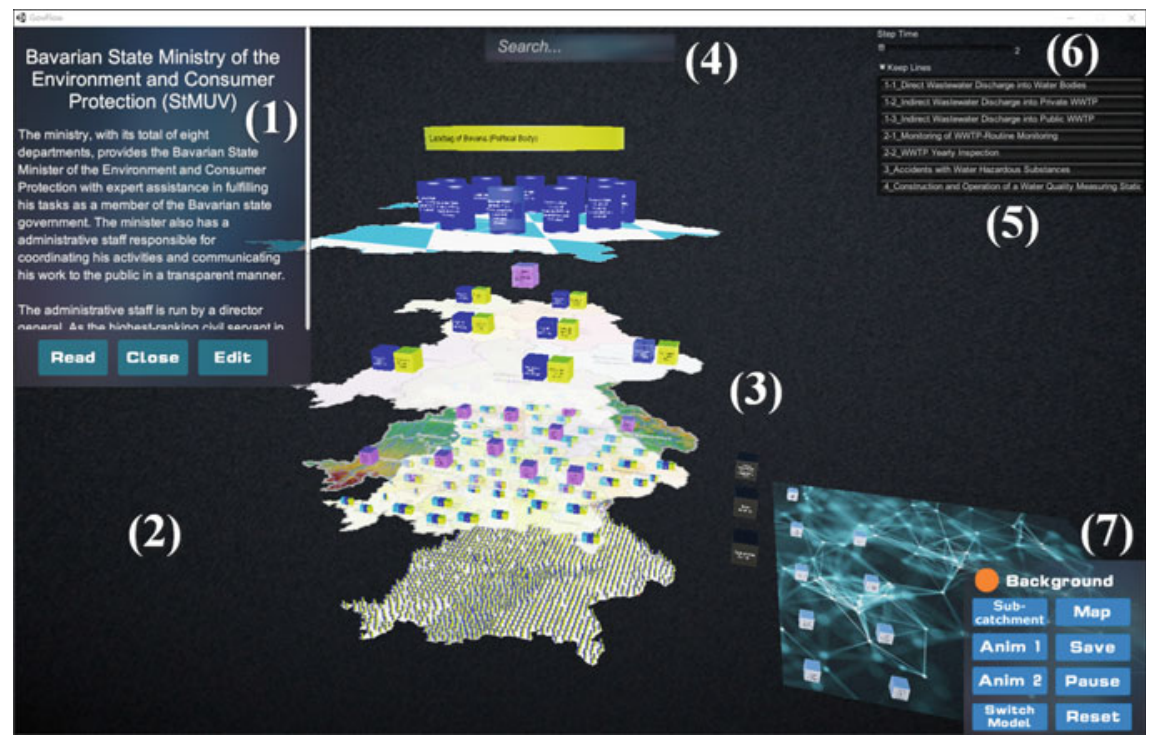

Fig. 1.2 Graphical user interface as the example of Bavarian 3D-WGM at default viewing angle 
action step is shown in sequence, which is accompanied by the corresponding explanation shown in the text box at second zone.

6. In the sixth zone, two options are situated for controlling the demonstration of dynamic process flows. The "Step Time" adjusts the speed of flow procedure; on the other hand, during the process flow, "Keep Lines" allows the users to either retain all the action lines on the UI or enable the action line to disappear before the display of the subsequent action line.

7. In the seventh zone, several interactive checkbox and buttons are designed, which allows general or additional operations and will be explained in succession. Checkbox "Background": it provides users the option to enable the display of the background panoramic picture or uncheck to hide the background. Buttons "Anim 1" \& "Anim 2": once activated, these two pre-made animations will automatically rotate and zoom through the main body of the 3D-WGMs from different angles, which gives comprehensive visual tour along and among the 3D constructions. Button "Switch Model": this button simply allows users to switch between the 3D-WGMs of Kunming City and Bavaria. Button "Subcatchment": analogue to a "spotlight" function, when it is required to selectively exhibit a specific group of organizations, and in the meanwhile hide other irrelevant organizations, this button could help to realize the requirement by appropriate pre-settings. In addition, more similar buttons could be added based on further necessities. Button "Map": by clicking this button, the window, which contains a list of all displayed maps in the $3 \mathrm{D}$ constructions, will present. At this moment, users have the possibility to separately keep or hide the desired maps. Button "Save": this button should be utilized when editing the position of a single or several organizations. After the editing operations, the "Save" button should be clicked to save the changes. Button "Pause": during the procedure of displaying water management processes or pre-made animations, pause button could be used to suspend these actions. Button "Reset": by clicking this button, the model will automatically bring the users back to view the 3D constructions at default angles.

8. The overall operation of the 3D-WGMs is realized by the combination of mouse and keyboard. It has been programmed that the two main buttons of the mouse are responsible for adjusting the viewing distance horizontally or vertically and changing the viewing angles at all directions. In addition, the mouse wheel button could be scrolled to zoom the $3 \mathrm{D}$ constructions at any depth. Thus, the 3D-WGMs could be observed at any level of details within the limitless 3D space (see Appendix A and Appendix B).

\section{Individual Organization and Internal Structure}

Each single organization forms as the basic unit of the 3D-WGMs and is assigned with its specific 3D shape. In general, most of the common organizations are designed with cube or cuboid shapes, in addition, some special organizations are built with cylinders and sphere shapes (Fig. 1.1, 1.2, 1.3). The size and proportion of each organization refer to its best fit with the map, which lies underneath. 

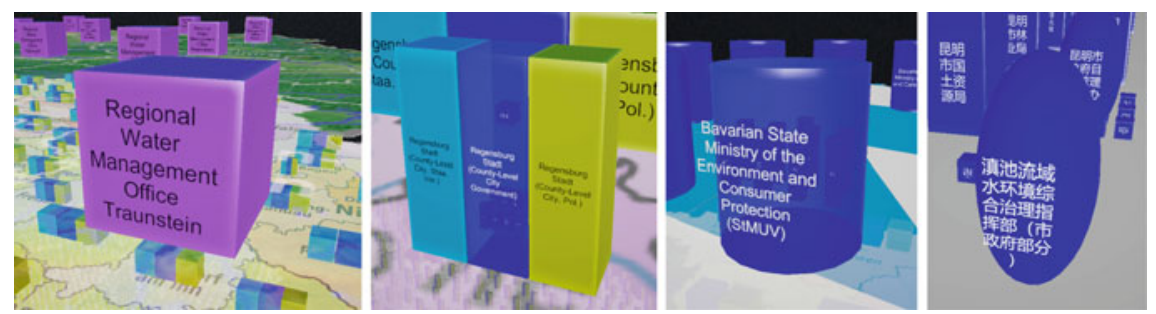

Fig. 1.3 Examples of individual organizations, which are assigned with cubic, cuboid, cylinder and sphere shapes

Table 1.1 The attributes of colors and corresponding indicated functions for the establishment of organizational shapes

\begin{tabular}{l|l}
\hline Colour name & Indicated function \\
\hline Red & Chinese Communist Party organizations \\
\hline Yellow & General political bodies \\
\hline Blue/Light Blue & General administrative bodies (two types of variations) \\
\hline Green & Water supply enterprises \\
\hline Brown & Wastewater treatment enterprises \\
\hline Dark green & Hybrid water supply and wastewater treatment enterprises \\
\hline Light Orange & Other types of enterprises \\
\hline Black & Organizations with temporary positions (need further adjustments) \\
\hline Pink & Technical institutions \\
\hline White & Social bodies \\
\hline
\end{tabular}

While each organization is established with its major purposes, it is thus necessary to assign color attribute to indicate its type of function. Several different typical colors are used to distinguish the most common organizational functions and is shown in Table 1.1.

Due to the models' 3D spatial characteristics, the internal structures could also be built within the 3D shape of any specific organization. The construction of internal structures could be extended to various scales, which is not only limited to two level of details. If one organization's internal structure has been designed, one simple click will bring user into the organization's internal view and conduct further observations. Figure 1.1, 1.2,1.3,1.4 gives an example of one organization's internal construction in three levels.

\section{Application of 3D Water Governance Models in Kunming City and Bavaria 3D Water Governance Model of Kunming City}

As illustrated in Fig. 1.5, the front view of the Kunming City WGM illustrates the Kunming water governance system in five official hierarchies, namely Yunnan provincial level, Kunming City level, county (district) level, township (sub-district) level and village (residential community) level. Although the model focuses on 

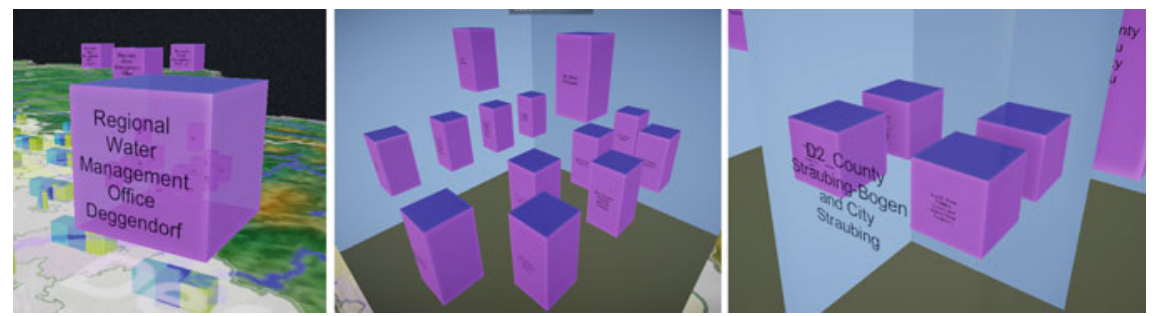

Fig. 1.4 Regional Water Management Office Deggendorf (WWA-Deggendorf) in Bavarian 3DWGM as an example to demonstrate the construction of organizations' internal structures. (a) represents the WWA-Deggendorf itself; (b) represents the first level internal structures; (c) represents the internal units of one specific department in WWA-Deggendorf

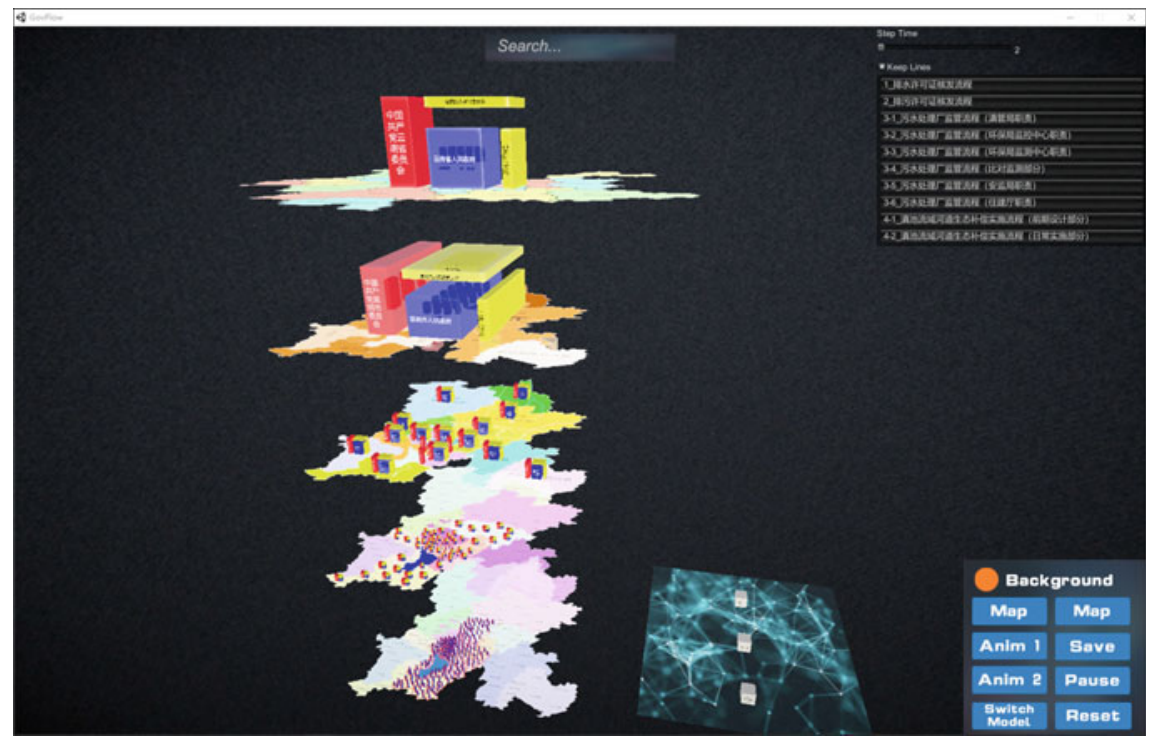

Fig. 1.5 The front view of Kunming City 3D-WGM

exhibiting the water governance model in Kunming City, the provincial organizations also play significant roles in local water administrations, thus they have been also incorporated in the model. In general, four major types of governmental groups, namely Party Committees, governments, People' Congresses (PC) and People's Political Consultative Conference (People's PCC), are widely and similarly established at each jurisdictional local region. While at lower hierarchies exceptions exist, where PCs are not established at village level and People's PCCs do not appear at both township and village levels. Different governmental groups play respective roles in governing all socioeconomic aspects, which include water resources.

In ordinary, local government is the highest administrative body in each region, which plays fundamental roles in administrating various socio-economic affairs. 
Local government should execute the resolutions from its corresponding PC and implement orders from higher administrative bodies, in the meanwhile, it also leads the administrative work of lower hierarchies within its jurisdictions. Local PC represents the highest power authority within its territory. Its major functions are formulating and promulgating necessary local regulations; ensuring the implementation of constitution, manifold laws and regulations; monitoring and examining the performances of its corresponding government etc. Local People's PPC serves as political consultative body to its related PC and Party Committee in the same region. Regarding the function and power of local Party Committee, it plays central and comprehensive roles in leading and coordinating the overall performance of local governmental groups. A local Party Committee is the prime organization in a given region to discuss and adopt the resolutions on major issues and policies, in the meanwhile, it is governed by a top-down approach, which is responsible to the Party Committee at the next higher level.

As illustrated in Fig. 1.5, most of the organizations related to water administration in Kunming City are displayed in 3D-WGM, which are based on their hierarchical and geographical positions. From higher to lower hierarchies, each level's major functions regarding water administration are described in the following lines:

\section{Provincial Level}

Governmental organizations in provincial level involve in Kunming City water administration by various approaches. Firstly, numerous significant water related local statues and regulations are promulgated at provincial level, and essential central policies are interpreted ahead in provincial level, which could further guide the implementations at lower hierarchies. Secondly, provincial government examines the water administrative performances at city level. In addition, some further core involvement mechanisms from provincial level also exist, such as financing broad range of projects and campaigns; setting specific targets, which is required to be achieved by lower hierarchies; and issue permissions for actions that have higher water environmental impacts.

\section{City Level}

City governmental organizations play central roles in administrating water resources in Kunming, especially for the urbanized regions. In the first place, amounts of water relevant regulations are issued by Kunming City government and PC, which are formulated for ensuring their applicability in Kunming. Secondly, essential concrete water administrative tasks are performed by various bureaus and intuitions (arranged as internal construction of Kunming City government in its 3D-WGM) in Kunming City government, those tasks cover broad range of water administration, such as issuing permissions for water extraction and wastewater discharge, conducting water quality monitoring, legal controls against unauthorized activities, and flood risk prevention. Furthermore, Kunming City also coordinates and supervises governmental organizations in county level for implementing water related socio-economic development plans and various local policies. 


\section{County Level}

17 county level groups of governmental organizations are demonstrated in the 3DWGM. In general, county levels are also responsible for executing routine water administrative tasks within their territories, while those tasks are either assigned by city level or required by relevant regulations. As described in city level, county levels are also responsible for fulfilling the assigned tasks of water planning and policies.

\section{Township and Village Level}

68 and 214 groups of respective township and village governmental organizations (within Dianchi Lake Basin) are exhibited in the 3D-WGM. Regularly, governmental organizations from both levels are not actively involved within significant water administration processes. Their main responsibilities usually consist of ensuring the functioning of water conservancy facilities, performing flood and drought risk controls and executing necessarily assigned duties from higher levels.

\section{D Water Governance Model of Bavaria}

As Fig. 1.2 captures the side view of Bavarian 3D water governance constructions. In total, four governmental hierarchies, namely ministry level, administrative district level (Regierungsbezirke), county or county-free city level (Landkreis or Kreisfreie Stadt) and municipality level (Gemeinde) constitute the foundation of governmental administration systems in Bavaria. Within each administrative region, governmental organizations are composed of political bodies and administrative authorities. Regarding the functionalities, each political body is in general the main organ of its administrative region, it decides on all the significant regional affairs and establish principles for the performance for its corresponding administrative authority. The highest political body (Landtag of Bavaria) in Bavaria has the authority to issue laws, while the other political bodies in lower hierarchies could only promulgate statutes or legal provisions, which are below laws and formulated based on the regional conditions. On the other hand, administrative authorities are responsible for executing routine administrative tasks and resolutions from their parliaments or councils. In the next lines, each governmental level will be described regarding their major functions for Bavarian water administration.

\section{Ministry Level}

Exhibited in the 3D-WGM as one of the 11 state ministries in Bavaria, the Bavarian State Ministry of the Environment and Consumer Protection (StMUV) functions as the highest state authority for water resource management. Its major responsibilities are firstly to operate as the sole legislative body that develops and implements various water relevant state laws and provisions. Secondly, StMUV provides guidance and monitors the overarching water administrative procedures in whole Bavaria, it goes through most essential decisions on water administration, issue permissions for substantial proposals and set management strategies for significant water environmental events. In addition, it also plays roles in national and international water resource and river basin commissions for transboundary cooperation. 
Subordinate to StMUV, LfU is the central public authority for managing environment related scientific and technical issues in Bavaria. It specializes in gathering and evaluating all aspects of water relevant data and further develops objectives, strategies, and plans for water environment protection. As advisory agency, LfU provides professional advices for public authorities and water management institutions, such as StMUV, Regional State Offices for Water Management (WWAs), and county water management offices. Equally important, it also bridges publics by providing raw or compiled water data, research or monitoring reports and forecast or warning service against hazards.

In addition, 17 WWAs are displayed in Bavarian 3D-WGM as special "expert" authorities in between district and county levels. WWAs are also established as subordinate technical public authorities to StMUV, and evenly distributed in Bavaria for executing local water tasks. They are by law "official experts" which means they are responsible to offer the know-how of the integrated water management on the regional level. In that meaning, they are independent official experts. In that role, the WWAs provide essential guidance and technical advices for county administrative authorities (which in legal meanings are responsible for the water management what means e.g. permitting water extraction and wastewater discharge applications, allowance for river construction and so on) and communities in terms of establishing and managing sanitation, water supply and wastewater treatment facilities. On the other hand, they are directly responsible for performing some delegated tasks from state, such as developing (e.g. flood protections, riparian restoration) and maintaining important state water courses, constructing and maintaining water infrastructure facilities including the associated properties, but especially the complete water monitoring system as chemical and biological water qualities, hydrology, etc.

\section{Administrative District Level}

Classified as the upper public water authorities (exhibited as second hierarchy in Bavarian 3D-WGM), seven district governments in Bavaria are mainly responsible for supervising and coordinating various water relevant stakeholders within their territories to realize a common solution or compromise, where issues could not be fully accomplished by local administrative authorities.

\section{County or County-Free City Level}

Overall, governments of 71 counties (Landratsamt) and 25 county-free cities (Kreisfreie Städte) are displayed at the third administrative level in the Bavarian 3D-WGM. The water rights units (specialist departments) situated in governments at county level are the offices responsible for ensuring water relevant laws and statues to be universally obeyed within respective county region. They are regarded as official authorities for water legal matters, thus, all water activities, which are required to be permitted or certified, shall be firstly examined and approved by the water rights units. In addition, they also make administrative decisions regarding illegal activities, water hazardous accidents, etc. 


\section{Community Level}

Ranked as the smallest administrative divisions in Bavaria, in total 2,031 communities are placed at the lowest level of Bavarian 3D-WGM. With the sovereign rights, communities are empowered to manage several water activities on their own responsibility, which include providing services for local water supply and wastewater treatment and managing the 3rd order water courses (1st and 2 nd order water courses are regarded as important water bodies, which are managed by the states).

\section{Water Management Processes}

One of the major applications of the 3D-WGMs is dynamically and stepwise demonstrating diverse water management processes. Since each water administrative system comprises numerous water management processes from different aspects, such as monitoring, water supply, wastewater treatment, and hydraulic construction, and not every process could be investigated in detail within this study, thus, four representative water management processes were chosen both for Kunming City and Bavaria, which are listed in Table 1.2. The table also indicates that some processes could contain sub-processes, depending on the actual local situations. This section will only select and elaborate one comparable process from each study area, namely issuing wastewater discharge permission into public sewage system in Kunming City and issuing permission for indirect wastewater discharge into public wastewater treatment plants in Bavaria (sub-project), to demonstrate as examples for introducing the displaying mechanism of water management processes in the 3D-WGMs.

Firstly, the management process issuing wastewater discharge permission into public sewage system in Kunming City aims at ensuring the wastewater discharge activities from different entities, such as industrial enterprises, individual businesses, and hospitals in Kunming urbanized region, to comply with the connectivity requirements with sewage system. This permission mainly examines that whether the local wastewater dischargers could safely transport their wastewater into public wastewater treatment plants. With essential keywords, Fig. 1.6a exhibits the entire flow diagram of this water management process, while the detailed stepwise description is attached in the Table 1.3 (in sequence of numbers shown in Fig. 1.6b). On the other hand, Fig. 1.6b displays the ending view of the same process, which is dynamically demonstrated in its 3D-WGM.

Table 1.2 Selected representative water management processes in Kunming City and Bavaria for the demonstration in 3D-WGMs. *N/A: Not applicable.

\begin{tabular}{l|l|l|l}
\hline Region & Process number & Sub-process number & Name of process \\
\hline Kunming City & 1 & N/A* & $\begin{array}{l}\text { Process of issuing wastewater } \\
\text { discharge permission into public } \\
\text { sewage system }\end{array}$ \\
\cline { 2 - 4 } & 2 & N/A & $\begin{array}{l}\text { Process of issuing permission for } \\
\text { general pollutant discharge }\end{array}$ \\
\cline { 2 - 4 } & 3 & N/A & $\begin{array}{l}\text { Process of monitoring wastewater } \\
\text { treatment plants }\end{array}$ \\
\hline
\end{tabular}


Table 1.2 (continued)

\begin{tabular}{l|l|l|l}
\hline Region & Process number & Sub-process number & Name of process \\
\hline \multirow{2}{*}{ Bavaria } & 1 & N/A & $\begin{array}{l}\text { Process of executing river ecological } \\
\text { compensation in Dianchi Catchment }\end{array}$ \\
\cline { 2 - 4 } & 1 & $1-1$ & $\begin{array}{l}\text { Process of issuing permission for } \\
\text { direct wastewater discharge into } \\
\text { water bodies }\end{array}$ \\
\cline { 2 - 4 } & 1 & $1-2$ & $\begin{array}{l}\text { Process of issuing permission for } \\
\text { indirect wastewater discharge into } \\
\text { private wastewater treatment plants }\end{array}$ \\
\cline { 2 - 4 } & 2 & $1-3$ & $\begin{array}{l}\text { Process of issuing permission for } \\
\text { indirect wastewater discharge into } \\
\text { public wastewater treatment plant }\end{array}$ \\
\cline { 2 - 4 } & 2 & $2-1$ & $\begin{array}{l}\text { Process of monitoring wastewater } \\
\text { treatment plants (routine } \\
\text { monitoring) }\end{array}$ \\
\cline { 2 - 4 } & 3 & 2-2 & $\begin{array}{l}\text { Process of wastewater treatment } \\
\text { plant yearly inspection }\end{array}$ \\
\cline { 2 - 4 } & 4 & N/A & $\begin{array}{l}\text { Process of dealing with accidents by } \\
\text { water hazardous substances }\end{array}$ \\
\cline { 2 - 4 } & 4 & $\begin{array}{l}\text { Process of constructing and } \\
\text { operating a water quality measuring } \\
\text { station }\end{array}$ \\
\hline
\end{tabular}

* Kunming DAB: Kunming Dianchi Administrative Bureau.

Secondly, the wastewater related permissions in Bavaria generally comprise three sub-processes (see Table 1.2). Regarding the sub-process issuing permission for indirect wastewater discharge into public wastewater treatment plants in Bavaria, it is responsible for ensuring the wastewater discharge activities are in compliance with the local corresponding sewage relevant regulations. Similarly, the entire flow diagram of this process is shown by Fig. 1.7a and its detailed stepwise descriptions are listed in Table 1.4 (in sequence of numbers shown in Fig. 1.7a). Additionally, Fig. 1.7b exhibits the spatial process flow, which is illustrated in the Bavarian 3D-WGM.

\subsubsection{Discussion}

\section{Strengths and Application Value of 3D Water Governance Models}

The development of 3D-WGMs has provided new approaches for comprehending local water governance systems. Several significant advantages of its application are discussed in the following lines.

The first strength of the 3D-WGMs indicates its integrative capability, which enables to display each single organization that is involved in local water governance system. Thus, this feature could give the model users the direct impressions of the system's dimension, regarding its layer of hierarchies, number of involved 
1 Improving Water Management and the Water Management System ...

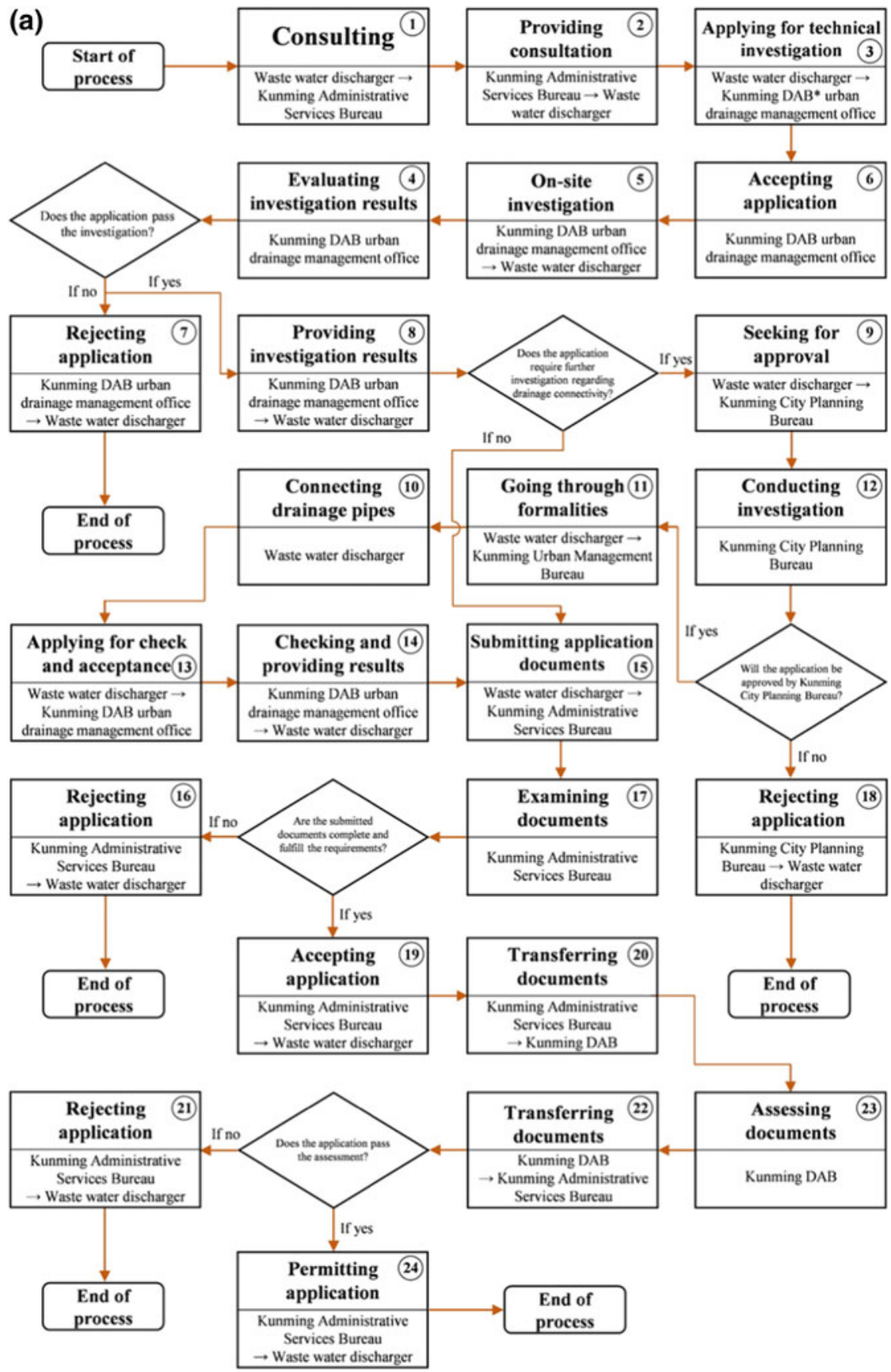

Fig. 1.6 Illustrations of water management process of issuing wastewater discharge permission into public sewage system in Kunming City. (a) 2D flow diagram of the entire processes; (b) exhibition of the process by Kunming City 3D-WGM, where all the options are answered with "yes" 


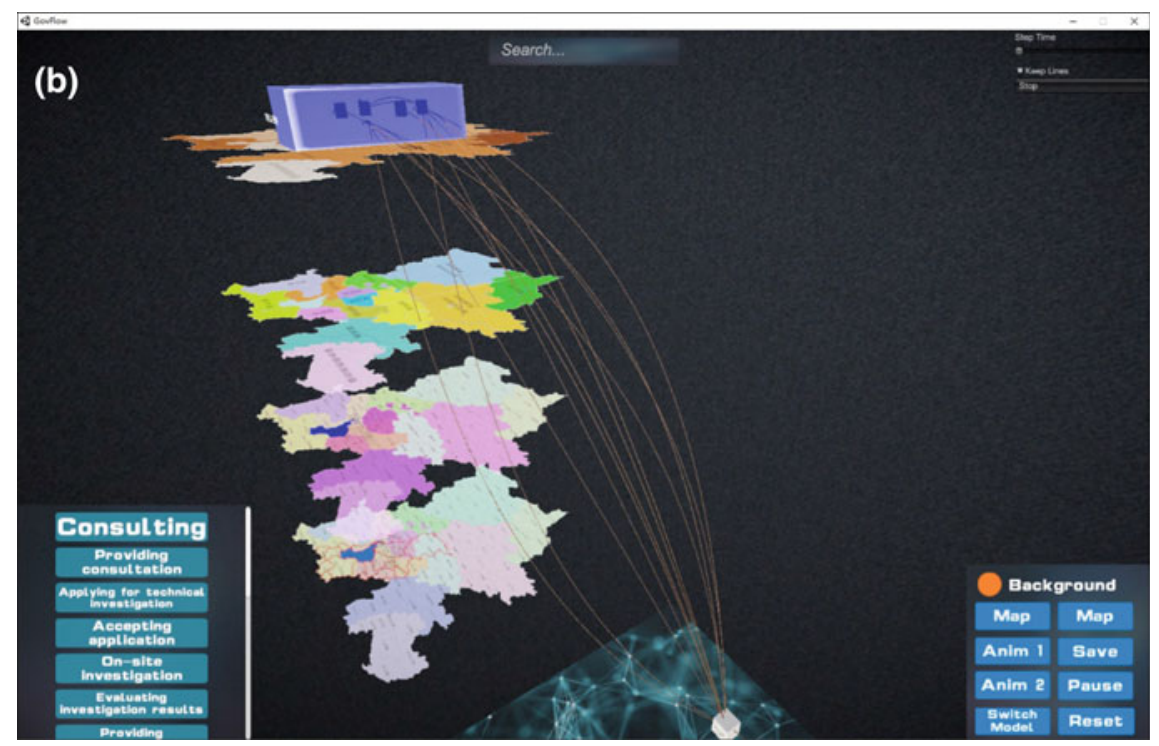

Fig. 1.6 (continued)

organizations and corresponding spatial location of each involved organization. On the other hand, each organization is built with independent 3D shape, which enables the users not only to observe the water governance system as a holistic structure, but also to zoom into the internal construction of any specific organization for further understandings. Hence, this feature allows to comprehend different water governance systems from both macro and micro perspectives. Comparing to the conventional 2D displays of the water institutional framework from several previous alike studies [8], MWE n.d.; [34, 44], the 3D-WGMs manifest their optimization of integrating different dimensional and complete structural information into one single framework.

The second advantage of using the $3 \mathrm{D}-\mathrm{WGM}$ is based on its $3 \mathrm{D}$ and interactive characteristics. On one hand, the 3D essence of the models allows users to observe the water governance systems from different angles and depths, which is adjusted to the users' preferences and requirements. On the other hand, with the programming results from Unity engine, the 3D-WGMs enable users to conduct various interactive operations, such as viewing institutional background information of different organizations, searching for specific organizations, hiding or displaying preferred institutions, generating observational animations, etc. Therefore, those interactive operations permit users to comprehend water governance systems based on individual requirements and focus on specific details. In comparison with previously mentioned studies, those institutional frameworks could only provide knowledge from one or several aspects, but not able to provide further interactive details from users' expectations.

The third significant feature of 3D-WGMs emphasizes that it combines the dynamic display of various water management processes within the models. Again, 
Table 1.3 Detailed step-wise description of the water management process issuing wastewater discharge permission into public sewage system in Kunming City (based on Fig. 1.6)

\begin{tabular}{|c|c|}
\hline Action step No. & Action step content \\
\hline 1 & $\begin{array}{l}\text { At the first place, the wastewater discharger should consult the Kunming } \\
\text { Administrative Service Bureau for general aspects of wastewater discharge } \\
\text { issues, knowing about its service domain, guidelines and forms for applying } \\
\text { permissions }\end{array}$ \\
\hline 2 & $\begin{array}{l}\text { Kunming Administrative Service Bureau will then provide consultations to } \\
\text { wastewater discharger for answering common questions regarding preparing } \\
\text { documents and application procedures }\end{array}$ \\
\hline 3 & $\begin{array}{l}\text { According to standard procedure, wastewater discharger applies for a } \\
\text { required technical investigation regarding drainage connectivity, which is } \\
\text { conducted by the Kunming DAB urban drainage management office }\end{array}$ \\
\hline 4 & $\begin{array}{l}\text { After technical investigation, Kunming DAB urban drainage management } \\
\text { office organizes experts to evaluate the investigation results, this step } \\
\text { examines whether the aspects, such as connection of pipelines, separation of } \\
\text { storm water and wastewater, utilization of recycled water etc., are in } \\
\text { compliance with the city regulations and requirements }\end{array}$ \\
\hline 5 & $\begin{array}{l}\text { Kunming DAB urban drainage management office then starts to assign } \\
\text { experts to conduct the technical investigation on-site }\end{array}$ \\
\hline 6 & $\begin{array}{l}\text { Kunming DAB urban drainage management office officially accepts the } \\
\text { application for technical investigation }\end{array}$ \\
\hline 7 & $\begin{array}{l}\text { If the application does not fulfil the requirement of the investigation, } \\
\text { Kunming DAB urban drainage management office will reject the application } \\
\text { from wastewater discharger }\end{array}$ \\
\hline 8 & $\begin{array}{l}\text { If the application passes the investigation, Kunming DAB urban drainage } \\
\text { management office will provide the investigation report to wastewater } \\
\text { discharger for further arrangements }\end{array}$ \\
\hline 9 & $\begin{array}{l}\text { If the application needs to apply further investigations regarding drainage } \\
\text { connectivity (for new or extended projects), the wastewater discharger then } \\
\text { need to seek for approvals by Kunming City Planning Bureau, who is } \\
\text { responsible for granting permission of road and drainage construction }\end{array}$ \\
\hline 10 & $\begin{array}{l}\text { Once approved, the wastewater discharger can start the construction to } \\
\text { connect its drainage system }\end{array}$ \\
\hline 11 & $\begin{array}{l}\text { If the application is approved by the Kunming City Planning Bureau, } \\
\text { wastewater discharger will then go through formalities to obtain the } \\
\text { approvals }\end{array}$ \\
\hline 12 & $\begin{array}{l}\text { When receiving the application, Kunming City Planning Bureau will } \\
\text { conduct its investigation regarding construction issues }\end{array}$ \\
\hline 13 & $\begin{array}{l}\text { Once the construction is finished, the wastewater discharger should then } \\
\text { apply by Kunming DAB urban drainage management office again for } \\
\text { checking the construction results and seek for its acceptance }\end{array}$ \\
\hline
\end{tabular}


Table 1.3 (continued)

\begin{tabular}{|c|c|}
\hline Action step No. & Action step content \\
\hline 14 & $\begin{array}{l}\text { Kunming DAB urban drainage management office further examines the } \\
\text { construction quality and gives comments back to wastewater discharger, } \\
\text { here inappropriate details should be changed and amended by wastewater } \\
\text { discharger }\end{array}$ \\
\hline 15 & $\begin{array}{l}\text { At this step, the wastewater discharger officially submits its application } \\
\text { documents to Kunming Administrative Service Bureau for standard } \\
\text { procedure of applying the permission. Here complete documents should be } \\
\text { submitted, which include application form, environmental impact } \\
\text { assessment report, business licenses, reports and assessment from previous } \\
\text { steps, etc }\end{array}$ \\
\hline 16 & $\begin{array}{l}\text { If the documents submitted cannot meet the requirements or not complete, } \\
\text { the Kunming Administrative Service Bureau can reject the application, or } \\
\text { ask for its re-submission }\end{array}$ \\
\hline 17 & $\begin{array}{l}\text { Once the Kunming Administrative Service Bureau receives the application } \\
\text { documents, it will start to examine the completeness and effectiveness of the } \\
\text { required documents }\end{array}$ \\
\hline 18 & $\begin{array}{l}\text { If the application is not approved Kunming City Planning Bureau, it can } \\
\text { reject the application from wastewater discharger or ask for amendments } \\
\text { and re-submission }\end{array}$ \\
\hline 19 & $\begin{array}{l}\text { If the received documents fulfil the requirements, the Kunming } \\
\text { Administrative Service Bureau will accept the application and give } \\
\text { confirmation documents to wastewater discharger }\end{array}$ \\
\hline 20 & $\begin{array}{l}\text { Kunming Administrative Service Bureau further transfers all the documents } \\
\text { to Kunming DAB for its final assessment }\end{array}$ \\
\hline 21 & $\begin{array}{l}\text { If the application is not approved, then Kunming Administrative Service } \\
\text { Bureau will inform the wastewater discharger about the decision of rejection }\end{array}$ \\
\hline 22 & $\begin{array}{l}\text { After assessment, Kunming DAB will make the final decision and deliver all } \\
\text { the necessary documents back to Kunming Administrative Service Bureau }\end{array}$ \\
\hline 23 & $\begin{array}{l}\text { When Kunming DAB receivers all the documents, it will conduct the final } \\
\text { assessment, which makes general examination by considering all relevant } \\
\text { aspects }\end{array}$ \\
\hline 24 & $\begin{array}{l}\text { If the application has been approved by the final assessment, then the } \\
\text { Kunming Administrative Service Bureau will issue the permission licence to } \\
\text { the wastewater discharger, and it can officially discharge wastewater } \\
\text { according to the requirement of permission }\end{array}$ \\
\hline
\end{tabular}

with application of the interactive functions from Unity engine, abundant water management processes could be built for each 3D-WGMs, which indicate how each single water management task is resolved by the communication and interactions among different relevant organizations. The display of each management process is designed with several key practical features, which are embedded within the models. Firstly, when any specific management process is triggered, the model will automatically hide the organizations, which are irrelevant to the process, this feature helps users to distinguish which are the involved organizations and where are they located. 
1 Improving Water Management and the Water Management System ...
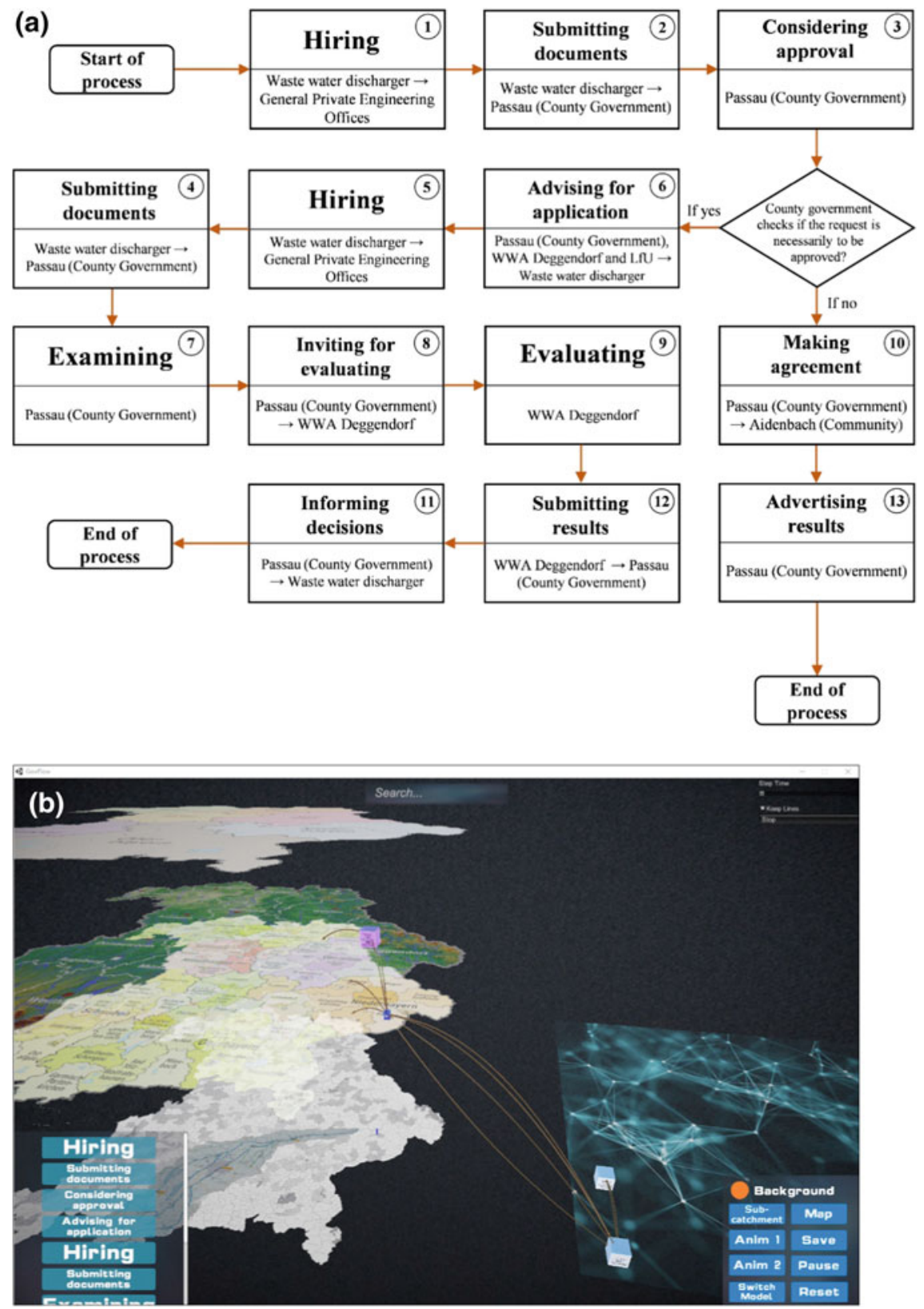

Fig. 1.7 Illustrations of water management process of issuing permission for indirect wastewater discharge into public wastewater treatment plants in Bavaria. Here the example is made by including Passau County Government, WWA Deggendorf and Aidenbach Community. (a) 2D flow diagram of the entire processes; (b) exhibition of the process by Bavarian 3D-WGM, where all the options are answered with "yes" 
Table 1.4 Detailed stepwise description of the water management process issuing permission for indirect wastewater discharge into public wastewater treatment plants in Bavaria (based on Fig. 1.7)

\begin{tabular}{|c|c|}
\hline Action step no. & Action step content \\
\hline 1 & $\begin{array}{l}\text { In the first place, the wastewater discharge applicant will need to hire engineering } \\
\text { office for helping to fill the necessary documents, which indicates the general } \\
\text { planning for its discharge activity }\end{array}$ \\
\hline 2 & $\begin{array}{l}\text { After the preparation of the general planning description together with the } \\
\text { engineering office, the wastewater discharger submits the documents to the } \\
\text { corresponding county government, here is Passau (County Government) }\end{array}$ \\
\hline 3 & $\begin{array}{l}\text { After receiving the descriptive documents, Passau (County Government) needs to } \\
\text { examine if the application should to be approved according to the relevant regulation, } \\
\text { namely the Waste Water Ordinance }\end{array}$ \\
\hline 4 & $\begin{array}{l}\text { Subsequently, the wastewater discharger submits its official application documents to } \\
\text { Passau (County Government) }\end{array}$ \\
\hline 5 & $\begin{array}{l}\text { After the application conference, ideally the wastewater discharger will hire the } \\
\text { engineering office again to prepare the official discharge application documents }\end{array}$ \\
\hline 6 & $\begin{array}{l}\text { If the approval is needed, then Passau (County Government) will initiate an } \\
\text { application conference, there it advises the wastewater discharger how to fill the } \\
\text { official application documents and inform about the contents and the extend of the } \\
\text { documents as well. When necessary, the Passau (County Government) will also invite } \\
\text { LfU and WWA Deggendorf to participate the application conference for consultation }\end{array}$ \\
\hline 7 & $\begin{array}{l}\text { After receiving the application documents, then the Passau (County Government) } \\
\text { checks their completeness and the sufficient effectiveness. If Passau (County } \\
\text { Government) finds that there are missing documents, then it will demand the } \\
\text { applicants to re-submit the corresponding documents. When necessary, LfU and } \\
\text { WWA Deggendorf should also get involved for helping Passau (County Government) } \\
\text { to check the received application documents }\end{array}$ \\
\hline 8 & $\begin{array}{l}\text { In the next step, Passau (County Government) sends all application documents to } \\
\text { WWA Deggendorf and invites the experts from WWA Deggendorf to conduct } \\
\text { professional assessment }\end{array}$ \\
\hline 9 & $\begin{array}{l}\text { Afterwards, the official WWA Deggendorf experts receive the documents, they } \\
\text { should start to evaluate the documents and formulate their expert opinions. This is } \\
\text { considered as the most significant step in the entire process, while their opinions } \\
\text { could significantly influence the decision of Passau (County Government). The } \\
\text { general task of the official experts is to investigate the facts and the associated effects } \\
\text { of the applications. According to the requirement of Administrative Procedure for the } \\
\text { Implementation of Water Law, the expert opinions should be created within a period } \\
\text { of three months. The experts should present the expected impacts of the application } \\
\text { on rights and the related legal interests of the involved parties, also including the } \\
\text { state. During the process, WWA Deggendorf experts should consider all the relevant } \\
\text { laws and regulations to formulate their proposals. The experts should also formulate } \\
\text { their opinions on their own responsibilities and not get other instructions. In order to } \\
\text { create this proposal, the experts need observe some guidelines for their work, for } \\
\text { example the expert report model and the information sheet from LfU. For their } \\
\text { participation in the processes, the official experts should be compensated for their } \\
\text { costs, as far as they could be charged from the wastewater discharger }\end{array}$ \\
\hline
\end{tabular}


Table 1.4 (continued)

\begin{tabular}{l|l}
\hline Action step no. & Action step content \\
\hline 10 & $\begin{array}{l}\text { If no approval is needed, then Passau (County Government) just needs to have an } \\
\text { agreement with the local drainage rules by the local municipality, which will allow } \\
\text { the applicant to discharge into the wastewater treatment plant in that community, here } \\
\text { is Aidenbach (Community) }\end{array}$ \\
\hline 11 & $\begin{array}{l}\text { Depending on the proposal from WWA Deggendorf, the Passau (County } \\
\text { Government) makes final legal decisions, they should inform the wastewater } \\
\text { discharger if the permission is granted or not. This decision is then not open for } \\
\text { discussion and only can be challenged later by the administrative court }\end{array}$ \\
\hline 12 & $\begin{array}{l}\text { At the end of the evaluation, the official experts from WWA Deggendorf should } \\
\text { submit their final proposal to Passau (County Government) which could be used as } \\
\text { the basis for its final decision on the application. In this proposal, the experts should } \\
\text { indicate that if the impairment of the application to the well-being of the public is not } \\
\text { a general concern and applies to the content and subsidiary regulations. On the other } \\
\text { hand, if not, the experts should indicate that the welfare of the publics is not secured, } \\
\text { although the existence of some secondary appropriate measures, then they suggest } \\
\text { rejecting to give the permission for discharge according to Federal Water Act }\end{array}$ \\
\hline 13 & \begin{tabular}{l} 
The Passau (County Government) should advertise publicly the results \\
\hline
\end{tabular} \\
\hline
\end{tabular}

Secondly, each action step of the processes is exhibited with logical sequences and accompanied by full literal explanations displayed parallel with the process flow. Thus, it facilitates that users could go through a stepwise explanation of any specific process and informed by rich description of each single step. It was also designed that the dynamic process could be paused at any moment. Thirdly, when the management processes are completely shown, all the previous action steps will be listed again, and users could at this moment replay any of the steps to conduct in-depth learnings, and in the meanwhile, this selected step will also be highlighted in the model. Therefore, this function provides the advantages to fully understand a process by post-learnings. While management processes are key elements of understanding the administrative mechanisms, organizational relationships and information flow [6, 36], Saleth and Dinar 2013), the integration of the management processes in the 3D-WGMs has facilitated to understand the connections among different organizations. In many circumstances, different water management processes are normally depicted by various kinds of 2D flowcharts, such as the examples that are existed by LfU (n.d.a, 2010) and [31]. In comparison, the most significant benefits of applying the management processes within the 3D-WGMs are that it is dynamically shown and integrates numerous management processes within one single model.

The application value of 3D-WGMs could be potentially seen in several fields. In the first place, water related governmental organizations at different hierarchies could adopt the 3D-WGMs for understanding own water governance systems from different perspectives. New ideas or improvement strategies could emerge, when governance structures are comprehensively examined. In addition, governmental organization could also utilize the 3D-WGMs as educative tool for training new employees and 
as guidance tool for facilitating employees' routine work. In the second place, 3DWGMs could also be provided to general publics for guiding citizens and different public groups to handle water related activities, such as applying permission for wastewater discharge, the requirements to construct and maintain small wastewater treatment facilities, etc. On the other hand, by providing the 3D-WGMs, it also indicates that local water administration respects the public relationships and governs water with more transparency. Finally, general researches could also apply the 3DWGMs as auxiliary tool for conducting comparative studies of water governance experience, further lessons could be learned when multiple 3D-WGMs are parallel compared and investigated.

\section{Limits of 3D Water Governance Models}

The 3D-WGMs have been developed with various benefits that are possible for potential practical applications, nevertheless, in this section some of their limited aspects will also be addressed for an objective discussion.

The first limit of 3D-WGMs arises from their complexity. While the models are developed analogous as a software, it instinctively would require a longer learning curve to get familiar with their mode of operations, design of UI, functionalities of various interactive fields, etc. In comparison with conventional 2D administrative frameworks or organizational charts, 3D-WGMs appear to be less forthright and more complicated, however, after investing adequate amount of learning time, the 3D-WGMs can be mastered with their full range of capabilities. Secondly, the maps utilized in the 3D-WGMs are currently represented by raster graphics, where geographic information could not be stored by each single 3D shape in the model. Thus, being lack of geographic attributes, limits exist that the models could not be operated with more realistic simulations. However, although without added information, the maps that are made from raster graphics could adequately fulfil the purposes of the establishment of 3D-WGMs. Thirdly, the 3D-WGM is currently at the ending phase of its development. While concerning to advance its practical applications in local water governance systems, further effort should be devoted to promoting its capabilities and persuading decision makers to integrate them into their management systems.

\section{Summary and Outlooks}

In this study, a novel and integrative 3D Water Governance Model (3D-WGM) was developed for demonstrating a complete local water governance system and displaying representative dynamic water management processes. Throughout this article, the model building tool was firstly introduced, and the model construction concept was explained. Subsequently, the functionalities of the model were elaborated, and two 3D-WGMs developed for Kunming City and Bavaria were in detail demonstrated for indicating the model's practical application. At the end, the strengths, application value and limits of 3D-WGMs were respectively discussed.

Regarding future work, several aspects could be considered to improve the functionality and extend the applicability of the 3D-WGMs. In the first place, more effective features could be integrated into the models, such as enabling vector-based 
maps, allowing assigning different attributes to organizations or action step of water management processes, and visualizing accountabilities among organizations. In the second place, more example studies can be conducted beyond local water management systems, such as at national and continental levels. In addition, with the facilitation of 3D-WGMs, future studies can comparatively articulate the water governance characteristics between Kunming City and Bavaria, and the 3D-WGMs could be accordingly improved to optimize the water governance system in study areas.

\subsubsection{Water Governance Structural Characteristics of Kunming City and Bavaria and Their Comparison}

\subsubsection{Introduction}

The remarkable growth in China's economy and population over the past three decades has caused tremendous degradation to the country's water environment. Since 1996, Chinese governments in different levels have begun to take actions to treat polluted water bodies and enhance overall water governance performances, those activities are closely embedded in the corresponding Five-Year-Plan and Major Water Program [5], Ministry of Ecology and Environment of China n.d.).

In order to facilitate Chinese Major Water Program, Federal Ministry of Education and Research of Germany (BMBF) and Ministry of Science and Technology of the People's Republic of China (MoST) has jointly initiated SINOWATER Project which aims at promoting Good Water Governance, management and innovative technologies for improving the water quality of two Chinese prominent and heavily degraded water bodies - Liao River Basin and Dianchi Lake Basin [9].

Designed as a contribution to water governance perspective of SINOWATER Project, this study selects Kunming City, China and Bavaria, Germany as study areas to systematically understand their respective water governance essential structural characteristics. In this study, qualitative interview analytical approach will be the first time parallel employed among water administrative systems in Kunming City and Bavaria. The results of the study will provide in-depth elaborations and comparisons of crucial water governance structural features from the study areas, which could further bring inspirations for the optimization of both water governance systems.

\subsubsection{Materials and Methods}

\section{Participants and Data Collection}

The data collection process consists of two phases of qualitative interviews, which both were conducted locally in our study areas - Kunming City and Bavaria.

The first phase of qualitive interviews was designed to collect data for systematically understanding the local water management fundamental structures and the 
major responsibilities of the interviewed organizations. For both study areas, semistructured interview type was determined as suitable approach for the research, and a purposeful snowball sampling strategy [30] was used to select most suitable interviewees. During the interview procedure, pre-designed interview guide was always employed for facilitating the entire process.

For Kunming City, the authors firstly established contacts with officers from Kunming Academy of Environmental Sciences (KAES), after negotiations and discussions, they have been fully informed with the purposes of the qualitative interviews and recommend 12 most representative water relevant organizations (Table 1.5) for conducting interviews. In addition, official letters were transmitted from KAES to those organizations for requesting cooperation. In the end, 7 individual interviews and 9 focus group interviews were conducted within 12 official organizations in 2016, in total, 38 people participated the whole interview procedure. The durations of individual interviews lasted around $1 \mathrm{~h}$, and the lengths of focus group interviews varied from 2 to $4 \mathrm{~h}$.

As to Bavaria, the authors consulted several officers from Bavarian water administrative system, who are also members of SINOWATER Project, they recommended 4 representative organizations (Table 1.6) for executing qualitative interviews and further helped to select suitable interviewees and arrange appointments. In the end, 5

Table 1.5 List of interviewed organizations in Kunming City

\begin{tabular}{l|l}
\hline $\begin{array}{l}\text { Kunming City interviewed organizations } \\
\text { (English name) }\end{array}$ & $\begin{array}{l}\text { Kunming City interviewed organizations } \\
\text { (Chinese name) }\end{array}$ \\
\hline $\begin{array}{l}\text { Kunming Academy of Environmental } \\
\text { Sciences (KAES) }\end{array}$ & 昆明市环境科学研究院 \\
\hline $\begin{array}{l}\text { Kunming Dianchi Administration Bureau } \\
\text { (KDAB) }\end{array}$ & 昆明市滇池管理局 \\
\hline $\begin{array}{l}\text { Kunming Environmental Protection Bureau } \\
\text { (KEPB) }\end{array}$ & 昆明市环境保护局 \\
\hline $\begin{array}{l}\text { Kunming Appraisal Center for } \\
\text { Environmental Engineering (KMACEE) }\end{array}$ & 昆明市环境工程评估中心 \\
\hline Kunming Dianchi Ecology Institute (KDEI) & 昆明市滇池生态研究所 \\
\hline Kunming Water Resources Bureau (KWRB) & 昆明市水务局 \\
\hline Kunming Dianchi Investment Co. Ltd (KDI) & 昆明滇池投资有限责任公司总部 \\
\hline $\begin{array}{l}\text { Kunming Dianchi Water Treatment Co. Ltd } \\
\text { (KDWT) }\end{array}$ & 昆明市滇池水务股份有限公司 \\
\hline $\begin{array}{l}\text { Kunming Dianchi Treatment and } \\
\text { Development Co. Ltd (KDTD) }\end{array}$ & 昆明滇池湖泊治理开发有限公司 \\
\hline $\begin{array}{l}\text { Kunming Dianchi Drainage Facilities } \\
\text { Management Company (KDDFMC) }\end{array}$ & 昆明排水设施管理有限责任公司 \\
\hline $\begin{array}{l}\text { Kunming Environmental Monitoring Center } \\
\text { (KEMC) }\end{array}$ & 昆明市环境监测中心 \\
\hline $\begin{array}{l}\text { Kunming Water Supply Group Co. Ltd } \\
\text { (KWSG) }\end{array}$ & 昆明自来水集团有限公司 \\
\hline
\end{tabular}


Table 1.6 List of interviewed organizations in Bavaria

\begin{tabular}{l|l}
\hline $\begin{array}{l}\text { Bavaria interviewed organizations (English } \\
\text { name) }\end{array}$ & $\begin{array}{l}\text { Bavaria interviewed organizations (German } \\
\text { name) }\end{array}$ \\
\hline $\begin{array}{l}\text { Bavarian State Ministry of the Environment } \\
\text { and Consumer Protection (StMUV) }\end{array}$ & $\begin{array}{l}\text { Bayerisches Staatsministerium } \\
\text { für Umwelt und Verbraucherschutz (StMUV) }\end{array}$ \\
\hline Bavarian Environment Agency (LfU) & Bayerisches Landesamt für Umwelt (LfU) \\
\hline District Government of Oberbayern (ROB) & Regierung von Oberbayern (ROB) \\
\hline $\begin{array}{l}\text { Regional State Offices for Water Management } \\
\text { - Munich (WWA-M) }\end{array}$ & Wasserwirtschaftsamt München (WWA-M) \\
\hline
\end{tabular}

individual interviews and one focus group interview were conducted within 4 official organizations in 2016, and in total 7 people participated the overall interview process. The reason why number of interviewees is much fewer in Bavaria than Kunming City is that much previous literature reviews have helped to identify significant amount of fundamental interview questions. The durations of individual interviews varied from $45 \mathrm{~min}$ to $1 \mathrm{~h}$ and the focus group interview lasted $1 \mathrm{~h}$. For both study areas, all participants' information was anonymized. The authors took field notes and digitally recorded the whole interview processes, afterwards all interviews were fully transcribed in Chinese, English and German, depending on the languages which were used during conversations.

Since understanding the characteristics of representative water management processes within our study areas is one of our major research targets (see Sect. 1.2.3.1.3), thus the second phase interviews were conducted both in Kunming City and Bavaria. During this process, as listed in Table 1.2, 4 representative water management processes were selected in each study area for in-depth investigation. The authors firstly gathered available documents about those management processes, then with the help of the previously contacted persons, corresponding experts and officers who are indeed involved within those management processes were identified, and further contacts were made to request for conducting interviews. Finally, adequate specific and more structured interviews were made with those experts and officers, and each single detail of those selected management processes was discussed and clarified. The lengths of those interviews varied from 1 to $2 \mathrm{~h}$. The information of those interviewees was consistently kept anonymous. During the interviews, the authors took field notes and organized them into detailed stepwise process descriptions, which are demonstrated alike as the examples Figs. 1.6 and 1.7 have shown.

\section{Data Analysis}

The authors read the transcripts and field notes numerous times, memos were written about their general and specific impressions. Then the data was analyzed according to the grounded theory approach, namely using constant comparative method to code it and find patterns and potential theories throughout the overall coding procedure [30]. Following the guidelines, the first step of the analysis was open coding, where data was examined line by line to identify the more detailed and specific characteristics 
about the water governance structures of Kunming City and Bavaria. In this step, authors got close to data and always allowed new ideas to emerge for formulating codes, and codes were constantly compared. In the meanwhile, authors constantly kept writing memos in order to record the emergence and transformation of various codes. In the next step, method of focused coding was adopted to re-examine and sort the initial codes (around 350 in total) in order to advance them into categories, which were more abstract and could theoretically tell the common essence of the subsumed codes. In the end, the most significant categories were selected for further elaboration in the results and discussion section. Throughout the analysis path, qualitative data software - Nvivo 12 was used to aid data analysis.

\subsubsection{Results and Discussion}

\section{Water Governance Structural Characteristics of Kunming City Extensive and Sophisticated Water Governance Constructions}

As has been introduced already in Sect. 1.2.3.1.3, five official administrative hierarchies with their different types of governmental organizations play roles in managing general water issues of Kunming City, where their basic functions on water governance have been shortly explained. Within those organizations, the interview study found that city government has the most essential force in administrating and managing concrete water management tasks, and the governmental information portal has shown that Kunming City government consists of numerous bureaus, offices and commissions, which jointly manage water resources (Kunming City Government n.d., Fig. 1.8). Within those organizations, the interview analysis recog-

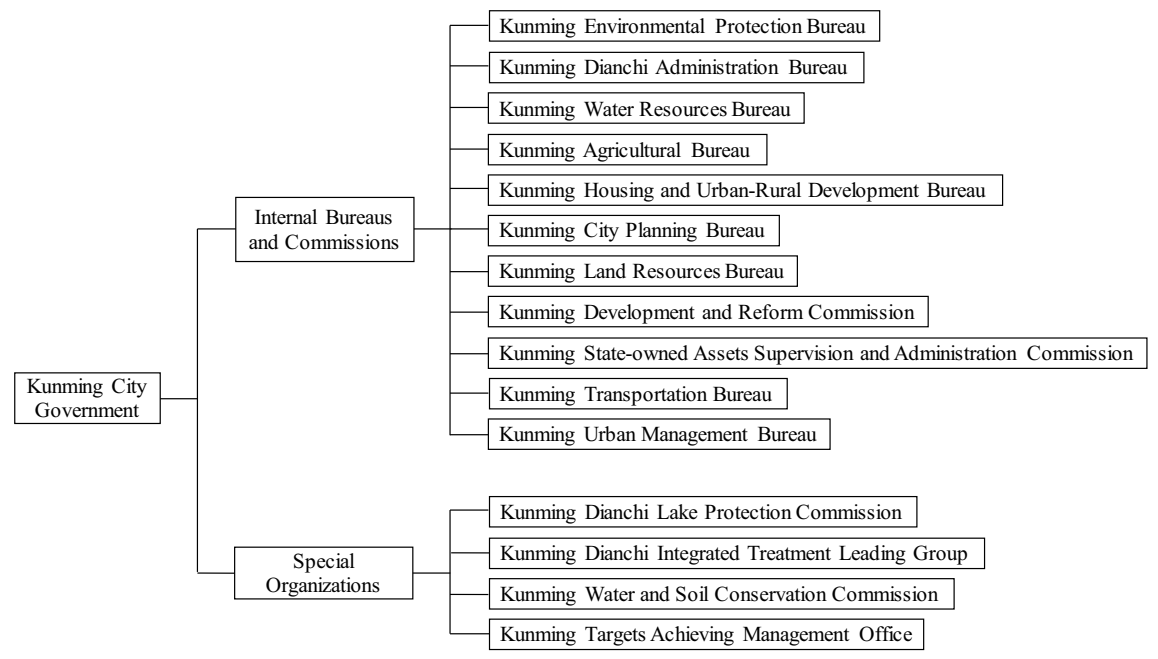

Fig. 1.8 Water governance engaged internal organizations of Kunming City government 
nized that KEPB, KDAB and KWRB could be regarded as the three most important water related city bureaus, they are established at parallel administrative level and function with different prime concerns. KEPB is mainly responsible for topics about water quality assurance, water pollution treatment and reduction as well as the corresponding legal and policy issues. KDAB is established as a bureau for managing, monitoring, legally controlling and coordinating Dianchi Lake Basin management and treatment issues. KWRB is then the bureau takes responsibility for general water resource management in Kunming City, where hydraulic, water supply, flood and drought risk issues are at focuses. Besides these three bureaus, there are also other parallel ones, which are partially responsible for water issues, for instances, Kunming Land Resource Bureau is responsible for partially managing groundwater that has heat values; Kunming Agriculture Bureau targets at water saving matters at agriculture sector; Kunming Transportation Bureau has rights to manage related issues on waterways, such as legal controls, traffic safety assurance and pollution emergency treatment, etc. Thus, we could relate that not only the central government consists 9 dragons that jointly manage water resources [43], but also this phenomenon can appear at local regions. One of the major reasons is that as in China, top-down management principle guides the general administrative sections, where local governmental constructions always have the tendency to imitate the settings from central and higher hierarchies, in this way, the principle facilitates the task breakdown, claims vertical leaderships and instructions. Evidences have also been found during the interview analysis, for example, after the establishment of KDAB at city level, the respective lower tier county governments also in succession established their own Dianchi Administrative Officers in orders to better coordinate with city tier. Of course, the internal constructions of lower tiers are not identical to higher tiers governments, mild variations could exist. Thus, when looking back at the internal constructions of Kunming City government, in comparison with the internal settings of provincial and county tier governments, city government constructions are slightly more specific, while more concrete tasks and management processes are assigned at city level, and it results in more detailed divisions of related bureaus. In general, when we see Kunming City government as whole, it is comprised of numerous independent and interlinked bureaus, and ahead of those bureaus, the central office also exists, which generally coordinates the working tasks of them.

Beneath city tier, there are three lower administrative levels existing in Kunming City, which are counties, townships and villages, with significant decreasing degree of involvement, each level's administration participates water resource management in its own practices. At these lower tiers, types and formations of their governments vary parallel, these differences are generally due to the different formations of communities, density of population, lifestyles and economic strengths. Regarding county tier, three different kinds of categories could be identified, which are 7 districts (more urbanized with stronger economic strength), 7 counties (less urbanized with lower economic strength) and 3 special districts (recently established for boosting development paces by high technologies, tourisms and investment purposes), in comparison, their governmental internal structures could vary at certain limited degrees, and in general less sophisticated than city level. From the interview analysis, we found that 
with respect to water resource management, county level is involved in some fundamental water administrations but with certain limitations. On one hand, county tier is engaged in multiple water management tasks, such as monitoring water qualities within their task ranges; conducting water legal controls; implementing central or higher-level policies (such as Five-Year Plan, Major Water Program, and Water Ten Items [4]) assigned projects, And providing services for water supply and wastewater treatment, if required. On the other hand, due to the top-down administrative principle, Kunming City government claims its leadership against county governments, thus, decisions and arrangements could be made that some fundamental water management rights are held rather in hands of city government, for example, counties could monitor quality of water bodies, only when city bureaus would not wish to perform or have assigned to them. Further evidences were found during the interview analysis, such as county tier does not have the rights to issue permissions for water extraction; and county governments could not provide water supply and wastewater treatment services if city government claims the responsibility already. In summary, the engagement of county governments in water sector could be stated that they are actively involved within wide aspects of water management tasks under the leadership and instructions from Kunming city government. Regarding the township and village levels, their degrees of involvement in water management are significantly lower than county level, and in most circumstances, they are responsible for ensuring the functioning of water conservancy facilities and fulfilling assigned duties from county tier.

As local governments are executing concrete administrative tasks, the local party committees besides are playing central roles in leading and coordinating their general performances. Party committees are extensively established at each administrative level and also govern strictly by the top-down principle, they form their own internal structures and the personnel are interwoven with their corresponding government settings. The analysis of the interviews found that at city level, multiple special organizations are formed together by Kunming City party committee and government, such as Dianchi Lake Protection Commission, Kunming Water and Soil Conservation Commission, and Dianchi Integrated Treatment Leading Group. Those organizations are normally led by the top leaders of party committees and government, on one hand they function to monitor the general performance of various management bureaus at same or lower levels, and on the other hand they create the platform to set up strategies, requirements and enhance communications among various water related bureaus and departments.

\section{Abundant Water Relevant Subordinate Authorities Scatteredly Exist}

Among general Chinese administrative systems, subordinate authorities exist as very important governmental organizations that are widely established at each level of government. Regarding water sector, those subordinate authorities are normally responsible for conducting concrete technical and professional water tasks on behalf of governmental bureaus, which are normally established attached to them. As with Kunming City, water related subordinate authorities are also established among different city bureaus, while the three most water relevant bureaus, namely KEPB, 
$\mathrm{KDAB}$ and $\mathrm{KWRB}$, manage many important ones. In this section, we will focus on discussing the interviewed subordinate authorities that are in the field of water research, development and monitoring, and we will use these examples to demonstrate how those water related subordinate authorities function and coordinate with each other.

Interview with Kunming Academy of Environmental Sciences (KAES) tells that firstly, there are two levels of Academy of Environmental Sciences (AES) existing in Yunnan Province, which is the single Yunnan Provincial Academy of Environmental Sciences (YAES), and multiple city level AESs established nearly for each city within Yunnan Province. For YAES, it is a subordinate authority of Yunnan Provincial Environmental Protection Department, while KAES is attached to KEPB, and all other city level AESs are also managed by their corresponding city Environmental Protection Bureaus (EPB). As with KAES, its intrinsic functions are conducting water related research tasks, such as investigating ecological restorations; pollution carrying capacity of specific water bodies; and modeling hydrological situations. On the other hand, due to the governmental characteristic, its primary responsibilities also include providing professional services and consultations to city government for facilitating management purposes, for example initiating and revising different kinds of planning. Thus, comments have been made by the interviewees that KAES is more functioning as an applied research institute, where limited fundamental research work takes place. Another interesting characteristic of KAES indicates that in comparison with other AESs from parallel cities of Yunnan Province, KAES is much well developed and organized than others, which is mainly due to the importance of Dianchi Lake, and in result, KAES has received much more attention and duties regarding Dianchi Lake treatment issues.

The interview with another important city level subordinate authority - Kunming Environmental Monitoring Center (KEMC) revels that firstly, Environmental Monitoring Centers (EMC) are established at three levels, namely province, city and county, and their primary responsibilities are conducting water quality related routine and specific monitoring tasks. For all the different EMCs, they are always established as subordinate authorities under their corresponding Environmental Protection Departments/Bureaus. For KEMC, it naturally conducts and coordinates the general water quality monitoring issues in Kunming City, and in specific, it executes routine water quality monitoring tasks for around 170 measuring points within city territory, where they perform the standard methods that are required by national standards and requirements. With professional equipment and facilities, KEMC could monthly produce monitored water environmental data, nevertheless, it is not able to fully monitor all the 170 required monitoring points, thus the numerous county level EMCs should act and help to fulfill the monitoring tasks if it is requested. In the end, county EMCs need transfer their monitored data to KEMC for comprehensive processing. With all the water quality monitored results, KEMC monthly reports and transfers the necessary data to Yunnan Provincial EMC for further producing reports to national government and general publics. Thus, here we could find that EMCs at different tiers have their own connections and cooperative mechanism, in fact, EMCs at higher level provide consultations, point out mistakes or areas for 
improvement, request and delegate tasks to lower EMCs, nevertheless, they do not hold the direct leadership to the lower ones, while this power belongs to the corresponding management bureaus. Some further phenomena have been discovered from the interviews at KEMC, for example, interviewees expressed that limited financial and personnel resources have caused great burdens to KEMC's over-saturated routine tasks; automatic monitoring points exist with different management patterns; water biological monitoring has not been maturely developed and only limited parameters are currently been monitored; online released water environmental data is released in very simple formats; and water quantity related monitoring tasks are performed by other independent subordinate authorities.

In summary, across governmental tiers, subordinate authorities widely exist and perform their required tasks, cooperative mechanisms exist among them for accomplishing miscellaneous and concrete water management tasks.

\section{Water Administrative Functions Spread Among Governance Constructions}

Water administrative functions are understood as the water relevant official authorities that hold the rights of explaining water related laws, policies and regulations and making decisions as well as processing water management issues, such as authorizing permissions, making punishment decisions, and rejecting water using applications. Water administrative functions could be thus regarded as important contribution for implementing water rights. In order to execute those administrative functions, they should be designed and arranged within their corresponding water governance constructions, and how those functions are performed is crucial for their effective implementations. Our interview study has found some essential characteristics of water administrative functions in Kunming City and will be introduced in this section.

In general, multiple interviewees from KEPB, KWRB and KDAB have emphasized that different administrative functions are spread among different water related bureaus across governmental tiers. Representative examples could be illustrated here that in the first place, there are water law and regulation related departments established in each water related bureau from city and county tier government, and in principle, they have the rights to design some essential local water regulations and policies at the initial stage, then they should be further revised by higher authorities, thus, those departments could work individually as well as cooperating to initiate various policies and regulations, depending on the concrete tasks. The second example is about issuing various water related permissions, which are regarded as essential approaches to reasonably and sustainably regulate anthropogenic activities that could cause adverse effect on water environment. three kinds of water related permissions are regarded significant in Kunming City, which are wastewater discharge permissions, waste discharge permissions and water drawing permissions. For wastewater discharge permissions, they are designed to verify whether the wastewater discharge activities are in accordance with the requirements to connect with existing drainage facilities. The interview found that for 5 of the urbanized counties, the permissions are together assessed and issued by KDAB, nevertheless, for other districts and counties, these permissions are then not granted systematically, while some counties issue them by other bureaus within their own governmental constructions, and some 
counties even do not issues them but just combine with other different permissions, for example city planning related permissions. Regarding waste discharge permissions, they indicate how much amount of different pollutants, including wastewater are granted to be discharged by specific entities. Depending on the types of waste dischargers, the permission issuing tasks are divided among city and county tier EPBs. In addition, the water drawing permissions are designed to ensure the reasonable water extraction and utilization. Regarding these permissions, county governments have no rights to issues them, while this responsibility is shared by the KWRB and provincial WRB, depending on the dimensions of the water extraction activities. The third example regarding scattered water administrative functions is about executing water legal controls, which are concerned as imperative ways to fight against illegal activities that bring harms to general water environment. In Kunming City, the task forces for water legal controls are distributed among various management bureaus, mainly include KEPB, KDAB, KWRB and their corresponding lower county tier bureaus. At city level, each task force from the 3 mentioned bureaus has its own focused task ranges to conduct water legal controls, for KEPB, it is more responsible for water pollution related incidents, which happen in urbanized regions, as with KWRB, its task force aims at fighting against activities that cause harm to water resource distribution, consumption and allocations, regarding KDAB, its task force has rights to handle comprehensive water legal issues within Dianchi Lake Basin. In fact, besides their independent working patterns, those task forces have their own interlinked mechanism that at necessity, they need to cooperate for investigating and processing more complicated water legal cases. As with county tiers, they hold their major responsibilities to process legal issues independently when the water cases are less significant and more rurally arisen, in addition, they also need to highly cooperate with task forces from city tier to provide local consultation and necessary assistances. Thus, water legal cases are normally resolved by single bureau or joint task forces from water bureaus across management tiers.

Besides the above more in detail mentioned water administrative functions, further examples have been found from the interview analysis and express that those functions are widely performed by joint administrative efforts: KWRB and KEPB both conduct studies on pollution carrying capacities of water bodies for guiding administrative decisions on pollution controls; KWRB and Kunming Land Resources Bureau both manage groundwater by different categories; Kunming Industry and Information Technology Bureau and KWRB both have rights to manage small scaled hydropower plants; various bureaus at different governmental tiers monitor and supervise the wastewater treatment plants (WWTP) in Kunming City urbanized regions; and with the example which has been mentioned in the above section that water monitoring tasks are executed and divided by numerous related subordinate authorities at various governmental tiers. 


\section{Highly Integrated Core Water Service Pattern for Kunming Urbanized Regions}

In Kunming City, the two water core service tasks, namely water supply and wastewater treatment are provided differently between urbanized and rural regions. In urbanized regions, where five economically better developed counties sit, their core water service tasks are centrally managed and served by large scale city controlled and owned companies. More concretely, at current situation Kunming Dianchi Water Treatment Co. Ltd (KDWT) manages 21 WWTPs that are distributed within Kunming City urbanized regions, and their treatment capacity can satisfy $90 \%$ population that settle there; on the other hand, Kunming Water Supply Group Co. Ltd (KWSG) integrally provides water supply service by its 13 subordinate Water Supply Enterprises (WSE), and its supply capacity has exceeded the overall demand from the urbanized regions. Since the water service providing companies have very strong political and governmental characteristics, they fully operate under the leadership of city government and city party committee in means of receving supports, supervisions and instructions. In fact, special commission, Kunming State-owned Assets Supervision and Administration Commission (KSASAC), has been long established to monitor the governmental controlled and managed companies, it aims at affecting them by appointing important personnel, modifying corporate structures, planning development directions, etc. Thus, in brief, core water services of Kunming City urbanized regions are highly controlled by city government.

As with rural regions, although this study has not made interviews at counties and lower levels in Kunming City, some interviewees have mentioned about the general conditions of their water core services, which could be summarized here after interview analysis. Firstly, core water services are not consistently managed and planned in rural regions, the management patterns of WSEs and WWTPs could vary, such as managed directly by local governmental bureaus, and private or semiprivate firms. Secondly, the scales and technology competence of water service firms are smaller and less advanced in rural regions, especially in rural townships and villages, it could happen that only very basic facilities are installed for water services purposes.

\section{Existing Water Management Processes Have Potentials for Further Refinement}

As has been introduced in Sect. 1.2.3.1.3, four representative water management processes have been analyzed, although with these few study examples, some very phenomenon process related characteristics could be identified and will be expressed in this section.

We have found that all these four studied management processes did not have previous ready-made comprehensive flow charts, thus it has required us to talk to different involved officers to clarify stepwise each single detail of studied water management process. After analyzing these collected process data, we firstly identified that fractional administrative functions of various bureaus could affect the sequential logic of different water management process, for example, within the process of WWTPs monitoring, continuous process has been split and interrupted 
due to diverse management scopes of different authorities, thus multiple independent small processes together can just tell the full mechanism of WWTPs monitoring. Secondly, it has been recognized that flaws within one specific water management process could be complemented by other similar or relevant process(es), the example goes that when we parallel investigated through the wastewater discharge and waste discharge permissions issuing processes, not one single process could entirely tackle the issue of granting wastewater discharge permissions, nevertheless, some flaws from both of the two related processes could be considerably complemented by each other. In addition, it has also been noted that within each studied management process, one or more executive steps of them were not thoughtfully designed or elaborated, while those steps were either not well defined by its description of step content or their logical sequences have not been clearly determined. Finally, from the example of ecological compensation implementation process, we found that when with primary governmental attentions, its action steps tend to be well designed in terms of logic and depth of details.

With those identified water management process characteristics, we could at least view that those required tasks have been executed in varied degrees of consummations, in the meanwhile, multiple potentials for further refinement have been recognized through their analysis.

\section{Dianchi Lake Witnessed the Continuous Evolvement of Governmental Constructions}

Referring to water resource management in Kunming City, the Dianchi Lake (Basin) has always played a very significant role in affecting the city's actions and policies for governing its water resource in general. Along history, Dianchi Lake has been important for the economy, tourism development as well as many aspects of residents' livelihood of Kunming City, and its severe pollution problem has attracted enormous governmental attentions and induced abundant treatment actions since the beginning of pollution (around 1986) till today. In fact, Dianchi Lake has witnessed some essential evolvement of governmental constructions, which will be introduced in this section.

Firstly, in 2002, KDAB was established in order to integrally resolve the severe pollution problem of Dianchi Lake, at that time, it was a very vanguard act to create a city bureau for managing a lake within the range of a city territory. Till today, $\mathrm{KDAB}$ is one of the most important core governmental bureaus of Kunming City, which plays significant roles in many aspects, including constantly coordinating with other traditional established bureaus. Secondly, for the better pollution treatment of Dianchi Lake, Dianchi Lake Protection Commission and the Dianchi Integrated Treatment Leading Group have been successively established, both are made up of city governmental and party committee high level leaders. With these two special commissions, the speed and coordinative efficiencies for Dianchi Lake pollution treatment has been greatly advanced. Thirdly, with the massive national policy River Master Program [7] been widely implemented all over China, Kunming City also created a special office named Dianchi Lake Basin River Master Program Office, which aims at thoroughly implementing River Master Program for Dianchi Lake 
Basin. In addition, as also mentioned above that due to the continuous treatment demands for Dianchi Lake, KAES has received amount of treatment and remediation related tasks along the historical stages, till today, the importance of Dianchi Lake has greatly influenced the internal constructions of KAES that more employees have been recruited, the department dealing with lake studies has internally become the most important one, etc.

\section{Water Governance Structural Characteristics of Bavaria Systematically Designed Water Governance Constructions}

As has been shown in Sect. 1.2.3.1.3 that the water governance system of Bavaria generally consists of 4 governmental levels and 2 types of technical oriented organizations, namely LfU and WWAs (Figs. 1.1, 1.2, 1.3, 1.4, 1.5, 1.6, 1.7, 1.8, 1.9), and their essential functions have been also briefly stated above. In this section, further fundamental governance structural characteristics will be demonstrated after interview analysis.

Beginning with StMUV, as the highest state authority for water resource management in Bavaria, it governs and influences water administration at strategic and diplomatic level. Internally, StMUV is comprised of multiple departments, and the Department 5, namely Department of Water Resource Management and Soil Protection is established with 10 working units that tackle water governance from different

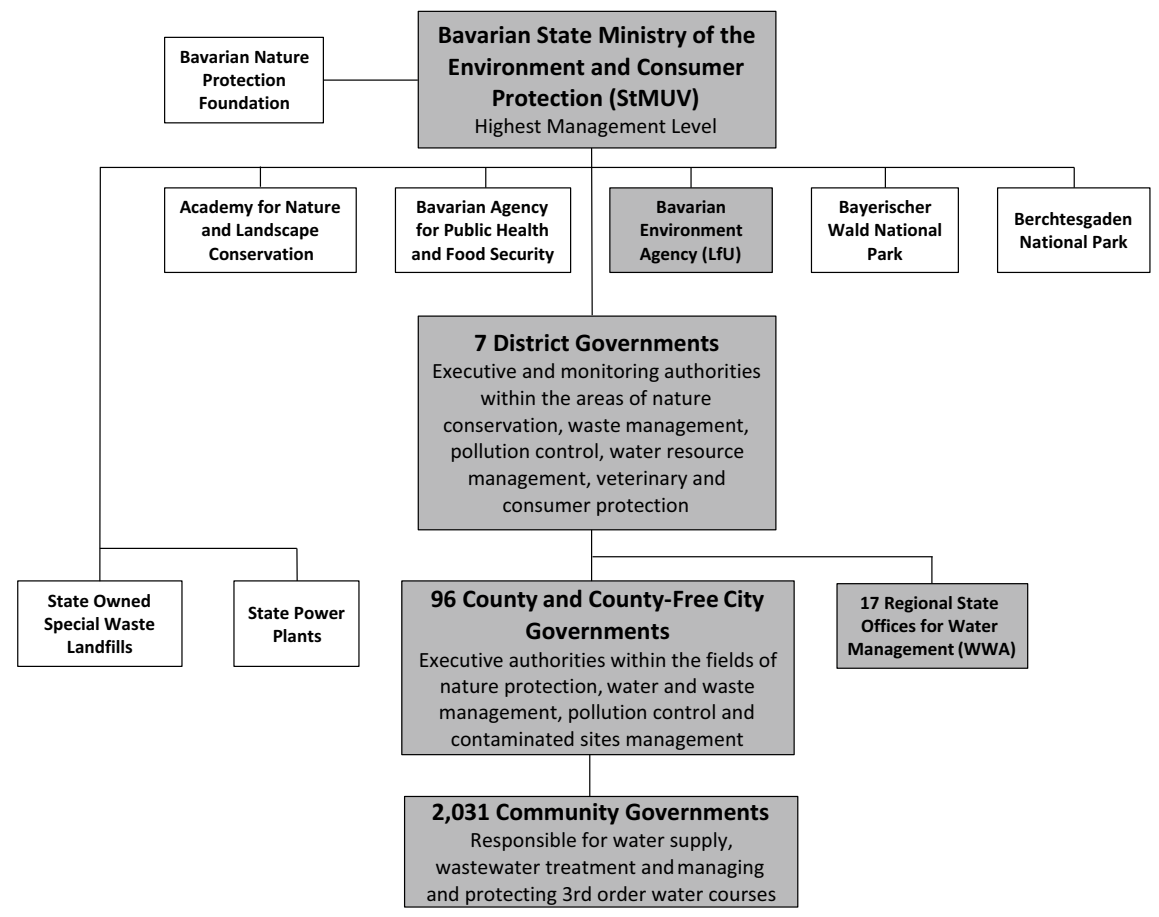

Fig. 1.9 Brief illustration of highlighted Bavarian water administrative organizations among general environmental protection governance system ( modified by authors, StMUV n.d.) 
concrete water aspects, such as water laws, national and international river basins, monitoring issues, water supply, and wastewater treatment. With this department formation, the StMUV is responsible for several major concrete water governance tasks. Firstly, it interprets and implements European and federal water legislations at state level, in the meanwhile, it also initiates and releases state water laws, regulations, policies and makes important administrative decisions for whole Bavaria. Thus, in principle, StMUV conceptually forms central strategies regarding water management in better and more holistic concepts. Secondly, since important water bodies (1st and 2nd order water bodies (LfU n.d.d)) are managed at state level, StMUV is then directly in charge of their development strategies, including generally regulating and supervising hydraulic constructions as well as initiating water body protection plans. In addition, StMUV oversees the management conditions of water supply, wastewater treatment within whole state and provides financial support for those enterprises on basis of necessity. Furthermore, StMUV actively involves within various national and international river basin commissions and maintains steady relationships with external and foreign bodies regarding sharing water resource management duties, responsibilities and rights.

Beneath ministry level, 7 district governments act as upper public water administrative authorities in Bavaria. Internally, each district government is comprised of multiple working branches, and the water administrative sector at district level is, for each district, identically established as working unit "Water Resource Management" under the working branch "Environment, Health and Consumer Protection". In general, water administration at district level is responsible for executing, authorizing, coordinating and monitoring various water issues that connect higher and lower tiers. More specifically, district water authorities at first directly supervise and monitor the activities of WWAs that are situated in the same district territories, they have the rights to apply funding from ministries for their WWAs and pre-examine important projects and plans initiated from them. Secondly, district water authorities monitor county governments at lower tiers for ensuring their water rights have been appropriately performed. Thirdly, they also have rights to fulfill administrative functions, when concerning more significant and cross-regional issues, at these conditions, district governments play roles in providing coordination and finding balanced resolutions. In addition, district water authorities should execute various orders and requests from higher ministries.

Under district level, 71 county and 25 county-free city governments form administrative nets for water governance at county tier. Since each county enjoys its power of self-administration, it has freedom to design its own suited governmental constructions, and results in internal department settings in various styles. Nevertheless, water rights unit is always built within each county government (normally under environmental related department) for fulfilling its responsibility of processing water related laws, statutes and legal matters, more details have been already introduced in the Sect. 1.2.3.1.3.

Ranked as the smallest administrative divisions, 2,031 community governments are formed throughout Bavaria. Since communities enjoy much entitled 
sovereign rights and administrate more independently than counties, their governmental constructions also differ according to local management conditions. Usually, different types of unions and firms are locally formed for providing communities water supply and wastewater treatment services, and practical working units are normally formed within community governments for the purpose of managing and protecting 3rd order water courses (LfU n.d.d).

By knowing in depth about the water governance construction in Bavaria and in combination with interview analysis, two prominent structural characteristics have been found. In the first place, although water management authorities in Bavaria are geographically distributed among several governmental tiers, they are usually regarded collectively as within one water governance system, where their hierarchies and functions have been officially illustrated and explained (StMUV n.d., Fig. 1.9). On the other hand, Human Resource Management for water administration in Bavaria is regarded as one independent system with its own rules on personnel mobility, it keeps on concerning personnel statistics and executing management measures for bringing personnel through diverse positions within Bavarian water administrative system. The second discovered water governance structure feature tells that the water governance style is uniform throughout Bavaria, it could be reveled from the facts that water rights units are widely and equally established for parallel local governments, although their respective governmental settings could vary to certain degrees, in addition, standard management measures and processes have been created, which are identically implemented at local conditions. Moreover, WWAs are distributed in the entire state to ensure each local region could receive same quality of water services.

\section{Formation of Integrated Technical and Scientific Oriented Water Institutions}

In Sect. 1.2.3.1.3, the functions of WWAs and LfU, namely Bavarian technical and scientific oriented water institutions, have been briefly stated. In this section, their organizational and more management patterns will be further illustrated.

Starting with WWAs, they exist with distinctive Bavarian characteristics, while most of other states in Germany do not establish statewide official institutions that only focus on conducting water management technical tasks. In total, 17 WWAs are evenly distributed in Bavaria, which guarantees that each county or county-free city could receive their equal consultative water management services, in addition, the distribution of WWAs also ensure fundamental water tasks could be parallel and locally executed. All WWAs are similarly formed in matrix styles, this special type of internal constructions enables that on one hand, each county or county-free city could have its own contact persons in its corresponding WWA, since the departments of WWAs are horizontally installed for providing service to one more multiple counties. Under those departments, working units are formed to conduct different categories of water tasks, namely water quality, quantity related and biological monitoring issues; water supply, groundwater and soil protection aspects; wastewater treatment as well as hydraulic constructions and water body development. On the other hand, based on those categorized tasks, vertical technical branches are set up, which constantly provide internal professional consultations to those working 
units at necessity. Besides resolving technical water tasks, WWAs are also in close connection and communication with diverse relevant social and public entities, such as Isar-Allianz (Isar-Allianz n.d.), Bund für Umwelt und Naturschutz Deutschland (BUND n.d.), state and local fishery associations, etc. WWAs on one hand receive complains, ideas and professional advices from those public entities, and on the other hand, WWAs also inform them in time about the administrative decisions, which are significant to their interest. In addition, WWAs are in first line having communication with private citizens, when citizen address their complains, doubts and questions to them and they should accordingly provide feedbacks to those citizens in a timely manner.

On the other side, LfU is established as subordinate authority to StMUV and stands as the integrated and highest water scientific institute for whole Bavaria, and being as the only official environmental agency, no further similar ones are formed at lower level governments. Internally, LfU consists of 10 departments tackling all environmental aspects, and among them, 5 departments are fully or partially engaged in numerous concrete water issues, ranging from water services, laboratory analysis and evaluations to research and development. Functioning as knowledge hub for water resource management in Bavaria, LfU firstly provides scientific consultations to StMUV prior to develop water development goals and strategies; secondly, LfU ensures the basis of WWAs' technical performances by supporting them with guidelines, practical measures and instructions when confronting technical difficulties; in addition, LfU is also available to water rights units in county governments for assisting to make proper administrative decisions; moreover, LfU centrally obtains and processes water data and further provides to publics for their own utilizing purposes.

With in-depth knowing about Bavarian water technical and scientific institutions, their establishment indicates the characteristic that without complicated institutional arrangement, water scientific and technical tasks are centrally executed by two types of institutions, namely WWAs and LfU, they broadly communicate with each other, local governments at different tiers as well as social entities to resolve practical water management issues.

\section{Decentralized Core Water Service System}

In Bavaria, there are currently around 2,300 WSEs, 3,250 water protection zones, 9,000 groundwater abstraction sites, 2,640 public WWTPs and 100,000 small scaled WWTPs distributed throughout the entire state territory [40]. Endowed with high power of self-administration, municipalities in Bavaria enjoy the sovereign rights of managing their own water supply and wastewater treatment services. In principle, it has been kept that core water services in Bavaria are decentrally and locally provided, since multiple advantages are believed to be gained by adopting this type of management pattern. In the first place, WSEs could be formed to adapt local environmental and socio-economic conditions, thus those enterprises, usually organized at small to medium sizes, could be more flexible to optimize themselves for fulfilling local requirements. Secondly, with local services, water is supplied with short distances thus could be delivered fresh to consumers, on the other hand, wastewater could also 
be swiftly transferred to WWTPs. In addition, source water could be better protected and easier to be traced, regarding WWTPs, risks could be reduced when confronting incidents.

Depending on local conditions, namely types and sizes of municipalities, population as well as industrial and residential settlements, water enterprises are organized in different ways. For larger cities, public firms are often established to handle water service tasks, those firms could be fully operated by local governments or managed with mixed type of business modes; in other conditions, those tasks could be undertaken by private companies, which should operate under the supervision of their corresponding governments. Regarding smaller sized communities, special purposed associations are usually formed to provide water services for single or multiple adjacent communities, where cooperation is recognized at necessity among them.

In order to enhance the operation performance of those abundant and scattered water service enterprises, special "neighborhood" program was officially launched [40], which provides professional communicating and training platforms for water enterprise employees from neighbor communities. Under this program, routine meetings are held to covey technical knowledge, resolve common difficulties and further train their personnel. Thus, performance qualities of the overall water enterprises could be considerably maintained even without great amount of administrative efforts.

\section{Maturely Designed Water Management Processes}

Alike the water management process study for Kunming City, we have also investigated 4 representative processes (see Sect. 1.2.3.1.3) for Bavaria, the analysis has identified several phenomenon characteristics and will be illustrated in this section.

In the first place, we have learned that numerous water management processes, including the 4 studied ones, have been previously designed within Bavarian water governance system, those processes are illustrated in form of 2D flow charts, which not only stepwise demonstrate the process sequences, but also identify each action step's responsible authority. Several interviewees in our study have expressed and believed that those standard designed process flow charts could provide solid guidance during practical implementations, and managers could quickly and clearly monitor the performance quality of those processes at operation. Secondly, the representative studies recognized that the action steps of each management process are usually in detail described, especially for those on-site activities, for example, working aids are concretely and in detail formulated by LfU for those Private Water Management Experts (PSW), who are engaged in officially authorized practical tasks, such as on-site monitoring WWTPs, and conducting laboratory evaluations. Besides, when the management processes are relevant to general publics, the corresponding information is usually released online or in other forms, which could be reached by public stakeholders for their preparation and better engagement, for example, leaflets are produced by LfU for guiding social entities and firms to apply for wastewater discharge permissions. Thirdly, it has been further noted that executive steps within water management processes are usually reflections of relevant laws and regulations. 
On one hand, the general goals, namely keeping water bodies in good ecological and chemical status, are often considered and reflected by concerned management processes, for example, when WWAs are evaluating the wastewater discharge applications from wastewater discharges, they heavily consider how those activities could adversely affect the water bodies regarding their current and target natural conditions; further example from the process of handling accidents with water hazardous substances require that the identified polluters should take actions to remedy pollutions for returning the affected water bodies as close to their previous natural statues. One the other hand, there are specific laws and regulations already existing, such as Bavarian Administrative Procedures Act (BayVwVfG), and Administrative Procedure for the Implementation of Water Law (VVWas), which specify the designed water management processes should adequately reflect their requirements. Lastly, our study found that continuous discussions and debates are held to optimize the outdated or controversial executive steps, for example, there are discussions regarding whether it is appropriate to inform the WWTPs' operators shortly prior to their on-site monitoring practice.

\section{Challenges of Bavarian Water Governance Requires Long Term Efforts}

In this study, besides the effective water management measures were broadly identified, we have also learned multiple prominent challenges that Bavarian water governance system is confronting.

Although much effort has been devoted to advancing and optimizing its water governance construction, several aspects, such as non-point source pollutions, groundwater contamination and treatment, micropollutants and new water hazardous substances in water bodies, reclamation of energy and materials, and climate change induced issues are continuously bringing challenges to Bavarian water management system. Since those aspects could not be resolved at once and always evolve at different historical stages, official authorities thus should always invest to develop and equip refined professional knowledge and technical measures to bring better answers and solutions.

Challenges also exist when there is necessity to negotiate with private entities for advancing water protection and development measures. Very typical example was given by the discussion with WWAs that in order to further implement natural restoration plans, considerable lands should be obtained and purchased from private owners, during this process, general doubts, objections as well as increasing prices of real estate are very typical obstacles that slow down those management plans.

In Bavaria, there are long-lasting conflicts existing between water and agriculture sections. One on hand, increasing and intensified agricultural activities constantly bring considerable amount of contaminations to groundwater and surface water, although efforts from water administrative authorities were devoted to intervening, limited success was achieved. The reason lies in that agriculture is regarded as crucial industry in Bavaria, their social unions together with administrative authorities thus possess very strong political voices, various special regulations were formulated in favor of their economic growth. The Bavarian water authorities consider that the breakthrough of effectively controlling pollution from agriculture sector not only 
requires stronger water administrative interference, but it also counts on the selfawareness from agriculture governance sections. On the other hand, in order to maintain reliable biological monitoring performance in Bavaria, fish data is very essential to the reach of water sectors, nevertheless, significant fish data is primarily held in hands of agriculture authorities, additional efforts are normally required to obtain those data by water institutions.

Furthermore, the recent personnel reform at Bavarian administrative system has greatly reduced the number of civil servants at water sector, which resulted in difficulties to reassign tasks on limited personnel for maintaining reliable water governance performances.

\section{Comparison of Water Governance Structural Characteristics Between Kunming City and Bavaria}

Essential water governance structural characteristics of Kunming City had Bavaria have been in detail illustrated in sections above. In this section, their fundamental features will be further summarized and compared in Table 1.7. Under different political and administrative systems, Kunming City and Bavaria also govern water resources differently in terms of management philosophies as well as concrete management measures. Nevertheless, it could not be claimed that any local water governance system is fully well established, which does not require further optimizations. Therefore, from our study, those comparisons between Kunming City and Bavaria could be used to bring inspirations for their further respective water governance optimizations.

Table 1.7 Essential water governance structural characteristics comparison between Kunming City and Bavaria

\begin{tabular}{l|l|l}
\hline Comparison keywords & Kunming city & Bavaria \\
\hline $\begin{array}{l}\text { General governance } \\
\text { principle }\end{array}$ & $\begin{array}{l}\text { Top-down governance principle } \\
\text { prevails, which indicates central } \\
\text { and higher-level governments } \\
\text { generally lead administrative } \\
\text { affairs of lower ones }\end{array}$ & $\begin{array}{l}\text { The subsidiarity principle } \\
\text { prevails, which indicates } \\
\text { governance tasks should be } \\
\text { distributed with all their rights } \\
\text { and obligations at the lowest } \\
\text { possible efficient level, thus it } \\
\text { ensures local } \\
\text { self-administration power }\end{array}$ \\
\hline $\begin{array}{l}\text { Internal structures of local } \\
\text { parallel governments }\end{array}$ & $\begin{array}{l}\text { Internal structures of local } \\
\text { parallel governments are } \\
\text { constructed with great } \\
\text { similarity but could differ at } \\
\text { varying degrees due to defined } \\
\text { types and economic strengths }\end{array}$ & $\begin{array}{l}\text { Internal structures of local } \\
\text { parallel governments vary with } \\
\text { larger differences (besides } \\
\text { district level governments) due } \\
\text { to self-administration rights }\end{array}$ \\
\hline
\end{tabular}


Table 1.7 (continued)

\begin{tabular}{|c|c|c|}
\hline Comparison keywords & Kunming city & Bavaria \\
\hline $\begin{array}{l}\text { Alikeness of cross-tier } \\
\text { governmental constructions }\end{array}$ & $\begin{array}{l}\text { Lower tier governments } \\
\text { significantly imitate the internal } \\
\text { structures of higher tiers }\end{array}$ & $\begin{array}{l}\text { Local governments design their } \\
\text { own internal structures, no } \\
\text { specific cross-tier imitation } \\
\text { patterns have been found }\end{array}$ \\
\hline $\begin{array}{l}\text { Water authority at each local } \\
\text { government }\end{array}$ & $\begin{array}{l}\text { Multiple water related bureaus } \\
\text { exist at each local government } \\
\text { and jointly administrate } \\
\text { miscellaneous water issues }\end{array}$ & $\begin{array}{l}\text { Only one water } \\
\text { department/rights unit is } \\
\text { formed at each local } \\
\text { government for administrating } \\
\text { water issues }\end{array}$ \\
\hline $\begin{array}{l}\text { Distribution of water } \\
\text { administrative functions }\end{array}$ & $\begin{array}{l}\text { Water administrative functions } \\
\text { are distributed among numerous } \\
\text { water related governmental } \\
\text { departments/bureaus across } \\
\text { hierarchies }\end{array}$ & $\begin{array}{l}\text { Water administrative functions } \\
\text { are separately held in hands of } \\
\text { water rights units from } \\
\text { corresponding local } \\
\text { governments }\end{array}$ \\
\hline $\begin{array}{l}\text { Political influence on water } \\
\text { administration }\end{array}$ & $\begin{array}{l}\text { Party committees set strategies } \\
\text { for local water development and } \\
\text { play central roles in leading and } \\
\text { coordinating significant water } \\
\text { governance issues }\end{array}$ & $\begin{array}{l}\text { Bavarian water governance } \\
\text { system appreciates professional } \\
\text { and technical administrative } \\
\text { foundation, which accepts } \\
\text { limited and necessary influence } \\
\text { from political field }\end{array}$ \\
\hline $\begin{array}{l}\text { Water technical and } \\
\text { scientific authorities }\end{array}$ & $\begin{array}{l}\text { Numerous water technical and } \\
\text { scientific authorities are } \\
\text { organized as subordinated } \\
\text { authorities attached to various } \\
\text { governmental bureaus across } \\
\text { administrative tiers, which } \\
\text { independently or jointly execute } \\
\text { technical and scientific water } \\
\text { tasks }\end{array}$ & $\begin{array}{l}\text { Two types of water technical } \\
\text { and scientific institutions } \\
\text { (WWAs and LfU) support and } \\
\text { provide services and } \\
\text { consultations to cross-tier local } \\
\text { governments, and together } \\
\text { execute integral technical and } \\
\text { scientific water tasks }\end{array}$ \\
\hline Core water service patterns & $\begin{array}{l}\text { Water resource is centrally } \\
\text { supplied, treated in urbanized } \\
\text { regions and less systematically } \\
\text { organized in rural regions }\end{array}$ & $\begin{array}{l}\text { Water resource is in principle } \\
\text { locally, namely within the reach } \\
\text { of respective municipalities, } \\
\text { utilized, treated and protected }\end{array}$ \\
\hline Water service enterprises & $\begin{array}{l}\text { City owned state companies } \\
\text { centrally provide water service } \\
\text { for urbanized regions, while } \\
\text { governmental controlled } \\
\text { enterprises at lower tiers } \\
\text { provide services for rural } \\
\text { regions, which could be } \\
\text { organized in different business } \\
\text { forms }\end{array}$ & $\begin{array}{l}\text { Ensured with power to locally } \\
\text { provide their own water } \\
\text { services, municipalities have } \\
\text { established abundant } \\
\text { self-controlled small to middle } \\
\text { sized water service enterprises }\end{array}$ \\
\hline
\end{tabular}


Table 1.7 (continued)

\begin{tabular}{l|l|l}
\hline Comparison keywords & Kunming city & Bavaria \\
\hline $\begin{array}{l}\text { Pre-designed water } \\
\text { management processes }\end{array}$ & $\begin{array}{l}\text { Significant water management } \\
\text { processes are less } \\
\text { systematically designed in } \\
\text { various forms of charts }\end{array}$ & $\begin{array}{l}\text { Significant water management } \\
\text { processes are systematically } \\
\text { pre-designed in flow charts, } \\
\text { which in detail indicate action } \\
\text { steps and each step's } \\
\text { responsible authority }\end{array}$ \\
\hline $\begin{array}{l}\text { Correlative water } \\
\text { management processes }\end{array}$ & $\begin{array}{l}\text { Correlative water management } \\
\text { processes generally exist, which } \\
\text { complement each other and } \\
\text { could also result in task } \\
\text { overlapping }\end{array}$ & $\begin{array}{l}\text { Water management processes } \\
\text { are usually designed more } \\
\text { comprehensively for resolving } \\
\text { independent water tasks }\end{array}$ \\
\hline Public participation & $\begin{array}{l}\text { Public participation is } \\
\text { adequately recognized, while } \\
\text { some water related information } \\
\text { is released to public in less } \\
\text { concrete forms }\end{array}$ & $\begin{array}{l}\text { Public participation is well } \\
\text { recognized and treated by } \\
\text { Bavarian water administration }\end{array}$ \\
\hline
\end{tabular}

\subsubsection{Conclusion}

In this study, qualitative interviews were conducted among water governance internal systems of Kunming City and Bavaria, those interviews were aimed at in-depth learning about their respective water governance constructions, concrete management duties, performance strengths as well as confronting challenges. By adopting grounded theory analytical methodology, their most essential water governance characteristics were in detail demonstrated and discussed, in addition, fundamental water governance features of Kunming City and Bavaria were comprehensively compared.

\section{References}

1. Ahmady GA, Mehrpour M, Nikooravesh A (2016) Organizational Structure. Procedia Soc Behav Sci 230:455-462

2. Bayerisches Landesamt für Statistik (2017) Bevölkerungsstand. https://www.statistik.bayern. de/statistik/bevoelkerungsstand/. Accessed 27 July 2018

3. BUND (n.d.) Wir über uns. https://www.bund.net/ueber-uns/. Accessed 24 June 2019

4. China Water Risk (2015) New 'Water Ten Plan' to Safeguard China's Waters. http://www. chinawaterrisk.org/notices/new-water-ten-plan-to-safeguard-chinas-waters/. Accessed 24 June 2019

5. China Water Risk (2016) China's 13th Five-Year Plan for Ecological \& Environmental Protection (2016-2020). http://www.chinawaterrisk.org/notices/chinas-13th-five-year-plan2016-2020/. Accessed 24 June 2019

6. Correia FN (2003) Institutional water issues in Europe. World Water Congress 11

7. Dai L (2015) A new perspective on water governance in China: Captain of the River. Water International 40:87-99 
8. Das Gupta A, Singh Babel M, Albert X, Mark O (2005) Water sector of bangladesh in the context of integrated water resources management: a review. Int J Water Resour Dev 21:385-398

9. Dohmann M, et al (2016) German contributions to the Major Water Program in China: "Innovation Cluster-Major Water". Environmental Earth Sciences 75

10. Evans JW, et al (2006) Environment matters at the World Bank: 2006 annual review (English), Washington, DC

11. Grambow M (2008) Wassermanagement: Integriertes Wasser-Ressourcenmanagement von der Theorie zur Umsetzung, 1st edn. Friedr. Vieweg \& Sohn Verlag, Wiesbaden

12. Grambow M (ed) (2013) Nachhaltige Wasserbewirtschaftung: Konzept und Umsetzung eines vernünftigen Umgangs mit dem Gemeingut Wasser. Vieweg+Teubner Verlag, Wiesbaden

13. Grambow M, Disse M, Chen K, Patalong H, Uhl H-D (2019) Sustainable Water Resource Management in China - Reflections from a Comparative Governance Perspective. In: Köster S, Reese M, Zuo J'e (eds) Urban Water Management for Future Cities, vol 12. Springer International Publishing, Cham, pp 283-301. doi: https://doi.org/10.1007/978-3-030-014889_13

14. Hassenforder E, Barone S (2018) Institutional arrangements for water governance. Int J Water Resour Dev 21:1-25

15. He J, Xu X, Yang Y, Wu X, Wang L, Li S, Zhou H (2015) Problems and effects of comprehensive management of water environment in Lake Dianchi. J Lake Sci 27(2):195-199

16. Isar-Allianz (n.d.) Grundsatzpapier, Ziele und Organisation der Isar-Allianz. http://www.isarallianz.de/aufgaben.htm. Accessed 24 June 2019

17. Jin X, Wang L, He L (2006) Lake Dianchi. Experience and Lessons Learned Brief:159-178

18. Kilgariff E, Fernando R (2005) The GeForce 6 series GPU architecture. In: Fujii J (ed) ACM SIGGRAPH 2005 Courses on - SIGGRAPH '05. ACM Press, New York, USA, p 29

19. Koohborfardhaghighi S, Altmann J (2017) How organizational structure affects organizational learning. J Integr Des Process Sci 21:43-60

20. Kunming City Government (n.d.) Kunming City Government Official Internet Portal. http:// www.km.gov.cn/. Accessed 24 June 2019

21. LfU (n.d.d) Allgemeine Daten zur Wasserwirtschaft. https://www.lfu.bayern.de/wasser/allgem eine_daten_wasserwirtschaft/index.htm. Accessed 24 June 2019

22. LfU (n.d.a) Amtliche Festsetzung von Überschwemmungsgebieten. https://www.lfu.bayern. de/wasser/hw_ue_gebiete/amtliche_festsetzung/index.htm. Accessed 27 July 2018

23. LfU (n.d.b) Das weiß-blaue Klima. https://www.lfu.bayern.de/wasser/klima_wandel/bayern/ index.htm. Accessed 27 July 2018

24. LfU (n.d.c) Mittelwerte des Gebietsniederschlags. https://www.lfu.bayern.de/wasser/klima wandel/bayern/niederschlag/index.htm. Accessed 27 July 2018

25. LfU (2010) Wasserschutzgebiete für die öffentliche Wasserversorgung

26. LfU (2017) Flüsse, Seen und Grundwasser in Bayern - Gewässer auf dem Weg zum guten Zustand

27. Liu J, Li J, Li L, Wang Z, Chen S (2017) Comprehensive analysis on spatial pattern of water resources shortage in Kunming City. J Yangtze River Sci Res Inst 34:6-10

28. Liu R, Cao X (2017) Pollution treatment of practices of Dianchi Lake in the past twenty years. Environ Sci Surv 36:31-37

29. Meng T (2016) Application of integrated river basin management in Dianchi basin. Chin J Environ Manage 3:53-59

30. Merriam SB (2009) Qualitative research: A guide to design and implementation / Sharan B. Merriam, Rev. ed. Jossey-Bass, San Francisco, Calif.

31. Ministry for the Environment of New Zealand (2009) How Does the National Environmental Standard Apply to Water and Discharge Consents? http://www.mfe.govt.nz/publications/ $\mathrm{rma} /$ draft-users-guide-national-environmental-standard-sources-human-drinking-water/4. Accessed 27 July 2018

32. Ministry of Ecology and Environment of China (n.d.) Major Science and Technology for Water Pollution Control and Treatment. http://nwpcp.mep.gov.cn/. Accessed 24 June 2019 
33. Ministry of Water and Environment of Uganda (n.d.) Institutional Framework for Water and Environment. http://www.mwe.go.ug/mwe/institutional-framework-water-and-env ironment. Accessed 27 July 2018

34. OECD (2014) Water Governance in the Netherlands. OECD Publishing

35. OECD (2015) OECD Principles on Water Governance

36. Pahl-Wostl C, Conca K, Kramer A, Maestu J, Schmidt F (2013) Missing Links in Global Water Governance: A Processes-Oriented Analysis. Ecology and Society 18

37. Saleth RM, Dinar A (2013) The Institutional Economics of Water: A Cross-Country Analysis of Institutions and Performance. World Bank and Cheltenham, UK: Edward Elgar, Washington, DC

38. Sengupta PK (2018) Industrial water resource management: Challenges and opportunities for corporate water stewardship. Challenges in Water Management. John Wiley \& Sons, Ltd, Chichester, West Sussex, Hoboken, NJ

39. StMUV (n.d.) Organisation im Bereich Wasserwirtschaft. https://www.stmuv.bayern.de/the men/wasserwirtschaft/wasserwirtschaft_in_bayern/organisation.htm. Accessed 24 June 2019

40. StMUV (2014) Bavaria, Land of Water: Sustainable Water Management in Bavaria. Bayerisches Staatsministerium für Umwelt und Verbraucherschutz, Munich

41. Wang Y (2018) Assessing Water Rights in China. Water Resources Development and Management. Springer Singapore, Singapore

42. Woodhouse P, Muller M (2017) Water governance - an historical perspective on current debates. World Dev 92:225-241

43. Yan F, Daming H, Kinne B (2006) Water resources administration institution in China. Water Policy 8:291-301

44. Yu X, Geng Y, Heck P, Xue B (2015) A review of China's rural water management. Sustainability 7:5773-5792

45. Yunnan Provincial Bureau of Statistics (2015) Yunnan statistical yearbook. China Statistics Press, Beijing

Open Access This chapter is licensed under the terms of the Creative Commons Attribution 4.0 International License (http://creativecommons.org/licenses/by/4.0/), which permits use, sharing, adaptation, distribution and reproduction in any medium or format, as long as you give appropriate credit to the original author(s) and the source, provide a link to the Creative Commons license and indicate if changes were made.

The images or other third party material in this chapter are included in the chapter's Creative Commons license, unless indicated otherwise in a credit line to the material. If material is not included in the chapter's Creative Commons license and your intended use is not permitted by statutory regulation or exceeds the permitted use, you will need to obtain permission directly from the copyright holder.

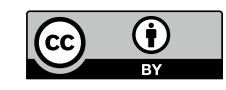

